\title{
New and known discolichens from Asia and eastern Europe
}

\author{
Ekanayaka AH ${ }^{1,2}$, Hyde KD', ${ }^{1,}$ Jones EBG ${ }^{3}$, Zhao ${ }^{1, *}$, Bulgakov TS \\ ${ }^{1}$ Key Laboratory for Plant Diversity and Biogeography of East Asia, Kunming Institute of Botany, Chinese Academy of \\ Sciences, Kunming 650201, Yunnan, China \\ ${ }^{2}$ Center of Excellence in Fungal Research, Mae Fah Luang University, Chiang Rai, 57100, Thailand \\ ${ }^{3}$ Dept. of Botany and Microbiology, College of Science, King Saud University, P.O Box 2455 Riyadh 11451, Kingdom \\ of Saudi Arabia \\ ${ }^{4}$ Russian Research Institute of Floriculture and Subtropical Crops, 2/28 Yana Fabritsiusa Street, Sochi 354002, \\ Krasnodar region, Russia
}

Ekanayaka AH, Hyde KD, Jones EBG, Zhao Q, Bulgakov TS 2019 - New and known discolichens from Asia and eastern Europe. Asian Journal of Mycology 2(1), 48-86, Doi 10.5943/ajom/2/1/2

\begin{abstract}
In the present study, lichenized discomycete taxa collected from northern Thailand, southern China, the UK, Ukraine and Russia are documented. Taxonomic studies of these taxa were carried out using both morphology and molecular data. Their phylogenetic relationships were inferred using LSU rDNA and ITS rDNA sequence data or combined analysis of these gene regions. Twelve lichenized discomycete taxa are reported in this paper including three new species (viz. Bacidia subareolata, Buellia sublauri-cassiae and Letrouitia magenta) and one reference species (Letrouitia transgressa).
\end{abstract}

Key words - 3 new species - apothecia - Lecanoromycetes - phylogeny - taxonomy - thallus

\section{Introduction}

A lichen is a symbiotic association between a mycobiont and a photobiont. This symbiotic association is generally bi-membered, which involves a single photobiont or tri-membered where two photobionts are involved (Fedorenko et al. 2012). Rarely bacteria and yeasts are also involved in the formation of lichens (Bates et al. 2011, Spribille et al. 2016). There are several morphological and ecology types of lichens: crustose, squamulose, foliose, umbilicate, fruticose and gelatinous. Crustose lichens are the most frequent type and characterized by a thallus, tightly attached to the substrate (Fedorenko et al. 2012).

Lichenized fungi mostly produce apothecia as their sexual reproductive structure and are known as discolichens or lichenized discomycetes (Ekanayaka et al. 2017). The apothecia of lichenized discomycetes bear four anatomical regions: epithecium, hymenium, hypothecium and exciple (collectively with ectal excipulum and medullary excipulum). The hymenial layer is composed of asci and paraphyses that are protected by the epithecium and supplemented by a hypothecium (Gueidan et al. 2014). The exciple acts as a wall or supporting tissue for the whole structure. Lichenized discomycetes have a worldwide distribution, frequently in terrestrial habitats and occasionally in aquatic and semi-aquatic habitats. They grow on various substrates, such as tree bark, wood, leaves, rocks and soil (Gueidan et al. 2014).

Lichenized discomycetes are mainly classified into three classes: Lecanoromycetes, Lichinomycetes and Arthoniomycetes (Ekanayaka et al. 2017), but Leotiomycetes and 
Dothideomycetes also include some discolichens (Lucking et al. 2016, Prieto et al. 2018). The first phylogenetic study on lichen-forming fungi based on ribosomal DNA sequence was by Berbee \& Taylor (1992). Later phylogenetic studies of Lutzoni et al. (2004), James et al. (2006) and Schoch et al. (2009) provided useful information regarding the phylogenetic position of lichenized apothecial fungi. Furthermore, Schultz et al. (2001), Ertz et al. (2009) and Miadlikowska et al. (2014) carried out detailed studies on this group.

In this study, we provide morphological descriptions of 12 lichenized discomycete taxa including three new species (viz. Bacidia subareolata, Buellia sublauri-cassiae and Letrouitia magenta) and one reference species (Letrouitia transgressa) from northern Thailand, southern China, the UK, Ukraine and Russia, supported by sequence data to infer their phylogenetic relationships.

\section{Materials \& methods}

\section{Sample collection and specimen deposition}

Specimens of lichenized discomycetes were collected in northern Thailand, southern China, the UK, Ukraine and Russia in 2015 to 2018. The specimens are deposited in the Mae Fah Luang University Herbarium (MFLU), Chiang Rai, Thailand and Kunming Institute of Botany Herbarium (HKAS). Faces of Fungi numbers were registered as described in Jayasiri et al. (2015).

\section{Observation of specimens}

Macroscopic and microscopic characteristics were recorded for the collected specimens. Sections of apothecia were made with a razor blade, mounted in water and preserved in lactoglycerol. A Motic SMZ-168 stereo microscope was used to observe the structure of apothecia. A Nikon ECLIPSE 80i microscope was used to observe microscopic characters. Photomicrographs were recorded with a Canon 450D digital camera fitted to the microscope. Measurements of apothecia, exciple, paraphyses, asci, and ascospores were made from materials mounted in water and the mean values were used in the descriptions. Measurements were made with the Taro soft (R) Image Frame Work v. 0.9.7 and images used for figures were processed with Adobe Photoshop CS6 software (Adobe Systems Inc.).

\section{DNA extraction, PCR and sequencing}

Genomic DNA was extracted directly from ascomata using a Plant DNA Rapid Extraction Kit (Bio Teke Corporation, Beijing, China). The internal transcribed spacers (ITS) were amplified with primers ITS4 and ITS5 (White et al. 1990) while primers LROR and LR5 (Vilgalys \& Hester 1990) were used to amplify nuclear ribosomal large subunit (LSU). The PCR mixtures $(25 \mu \mathrm{L})$ contained ddH2O $(11 \mu \mathrm{L})$, PCR Master Mix (TIANGEN Co., China) $(11 \mu \mathrm{L} ; 2 \times)$, DNA template (1 $\mu \mathrm{L})$, each primer $(1 \mu \mathrm{L} ; 10 \mu \mathrm{M})$. PCR amplification conditions for all regions were consisted an initial denaturation step of $5 \mathrm{~min}$ at $94{ }^{\circ} \mathrm{C}$ and final extension step of 7 minutes at $72{ }^{\circ} \mathrm{C}$. For the LSU amplification, the 35 cycles consisted of denaturation at $94{ }^{\circ} \mathrm{C}$ for 1 minute, annealing at 56 ${ }^{\circ} \mathrm{C}$ for 50 seconds and elongation at $72{ }^{\circ} \mathrm{C}$ for 3 minute and for the ITS amplification the 35 cycles consisted of denaturation at $94{ }^{\circ} \mathrm{C}$ for 1 minute, annealing at $55{ }^{\circ} \mathrm{C}$ for 50 seconds and elongation at $72{ }^{\circ} \mathrm{C}$ for 1 minute. The PCR products were viewed on $2 \%$ agarose gels stained with ethidium bromide. PCR products were sequenced by Sunbiotech Company, Beijing, China.

\section{Sequence alignment and phylogenetic analysis}

Sequences generated from different primers were analysed with other sequences retrieved from GenBank. The related sequences were obtained from a BLAST search and from recently published data. The newly generated sequences were deposited in GenBank. The consensus sequences for each gene were aligned using MAFFT v. 6.864b (http://mafft.cbrc.jp/alignment/server/index.html) and manually adjusted in BioEdit v. 7.0 .4 (Hall 2004) where necessary. Incomplete portions at the ends of the sequences were excluded from the 
analyses. The individual datasets were concatenated into a combined dataset using FaBox (1.41) (Villesen 2007). Ambiguously aligned regions were excluded and gaps were treated as missing data. Maximum likelihood phylogenetic analyses were performed in CIPRES webportal (Miller et al. 2010) using RAxML-HPC2 Workflow on XSEDE (8.2.9) tool. The combined gene analysis was carried out using default conditions. The best scoring trees were selected. The resultant trees were viewed with FigTree v.1.4.0 (http://tree.bio.ed.ac.uk/software/figtree/). Maximum Likelihood bootstrap values equal or greater than $50 \%$ are given near the nodes.

\section{Taxonomy}

\section{Lecanorales}

This order was established by Nannfeldt (1932). Taxa form lichen thalli with protococcoid green photobionts (Crespo et al. 2010, Miadlikowska et al. 2014) and members are widely distributed (Kirk et al. 2008, Ekanayaka et al. 2017).

\section{Lecanoraceae}

This family was established by Körber (1855), a widely distributed family with species found commonly on rocks, soil or bark (Kalb et al. 2011). Species are characterised by apothecial ascomata, sparingly branched paraphyses, semifissitunicate cylindrical to clavate asci and ellipsoid, subglobose or bacilliform, hyaline ascospores (Kalb et al. 2011).

\section{Lecanora}

The genus Lecanora was introduced by Luyken (1809). Taxa are widespread and characterized by crustose lichen thalli with thalline apothecial margins, clavate asci and hyaline, aseptate ascospores (Grube et al. 2004, Śliwa et al. 2012, Wijayawardene et al. 2017).

Lecanora hagenii Rabenh., Flecht. Europ.7: no. 174 (1857)

Fig. 2

Facesoffungi number: FoF05800

Lichenized on dead stems. Thallus: crustose, grey to green, granulose. Sexual morph: Apothecia $0.5-0.8 \mathrm{~mm}$ diam., arising singly or in small groups, sessile, slightly erumpent from the thallus, cupulate to pulvinate, roundish, grey. Hypothecium convex. Margins concolorous to receptacle. Disc brown to orange. Hymenium hyaline, within a thick gelatinous matrix. Epithecium branched and pigmented paraphyses apices form clearly distinguishing pseudo epithecium above the hymenium, brownish. Excipulum 50-55 $\mu \mathrm{m}$ at flanks, composed of large, thin-walled, brownish cells of textura angularis to globulose. Paraphyses 3-4 $\mu \mathrm{m}$ wide at tips, numerous, filiform, obtuse and branched at the apex, septate, brown pigmented. Asci 30-35 $\times 7-15 \mu \mathrm{m}, 8$-spored, cylindrical to globose, short sessile, rounded at the apex, narrowed to the base. Ascospores 8-10 $\times 3.5-4.5 \mu \mathrm{m}$, multi-seriate, hyaline, smooth and thick walled, ellipsoid. Asexual morph: Undetermined.

Material examined - Russia, Rostov region, Shakhty City, stony steppe on slopes near Grushevka River (N 47.72279 ${ }^{\circ}$, E $40.25434^{\circ}$ ), on dead stems of Pontic endemic plant Scrophularia donetzica Kotov (Scrophulariaceae), 14 May 2015, Timur S. Bulgakov, T-396 (MFLU 16-0605).

GenBank accessions - ITS-MK499339

Notes - Our collection of Lecanora hagenii from Russia clustered with L. hagenii (Lh2) collections from Hungary (Śliwa et al. 2012). GenBank blast results shows that ITS data of our collection were $99 \%$ similar to that of L. hagenii (Lh2) and the clade received $100 \%$ bootstrap support. These two L. hagenii sequences formed a monophyletic clade close to L. dispersa (Fig. 1). Moreover, morphology of our collection is similar to the description of L. hagenii provided by Śliwa (2007). This species is common in both tropical and temperate regions (Śliwa 2007). Zhurbenko \& Notov (2015) and Ismailov et al. (2017) previously recorded L. hagenii from Russia, but it is the first record of this species from Rostov region. 


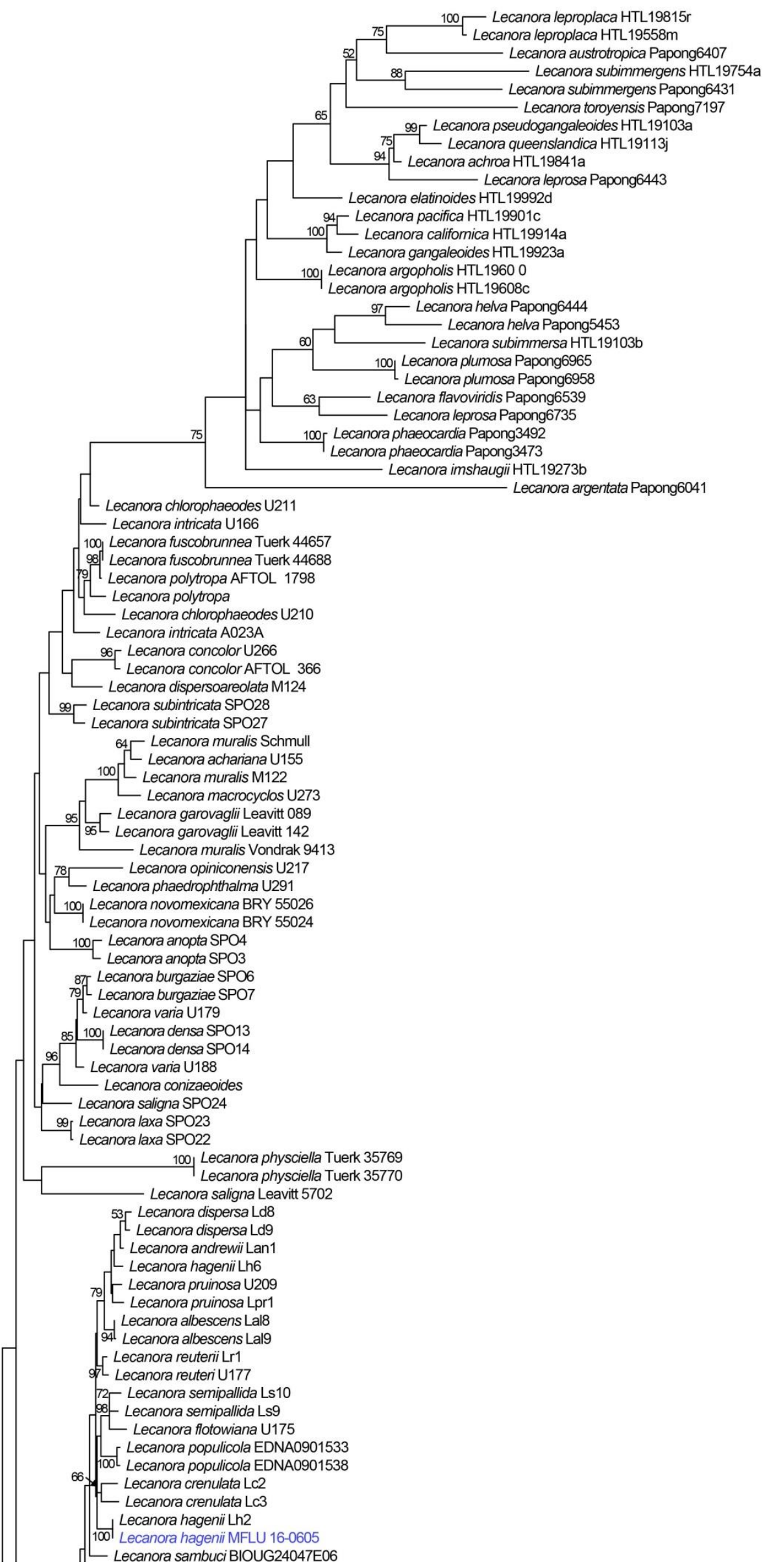




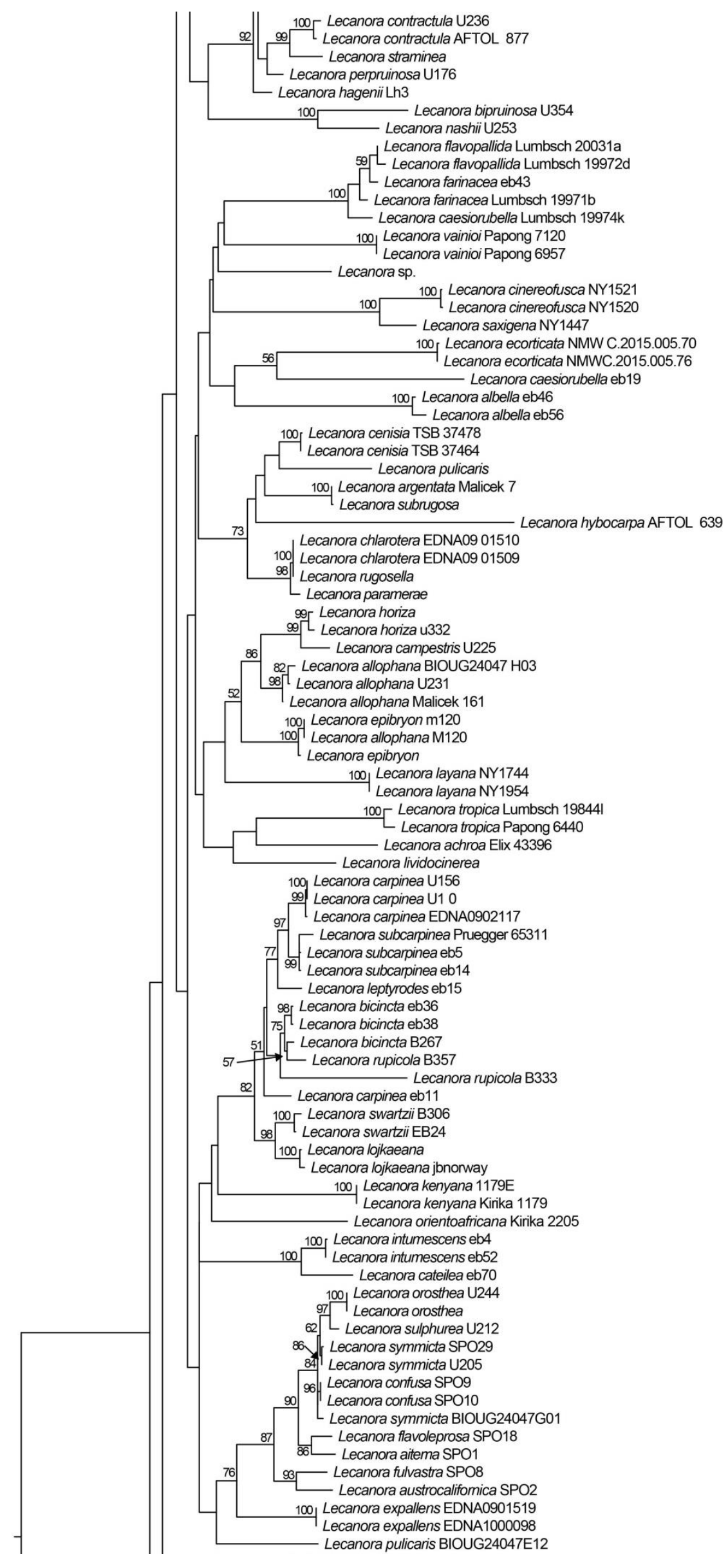




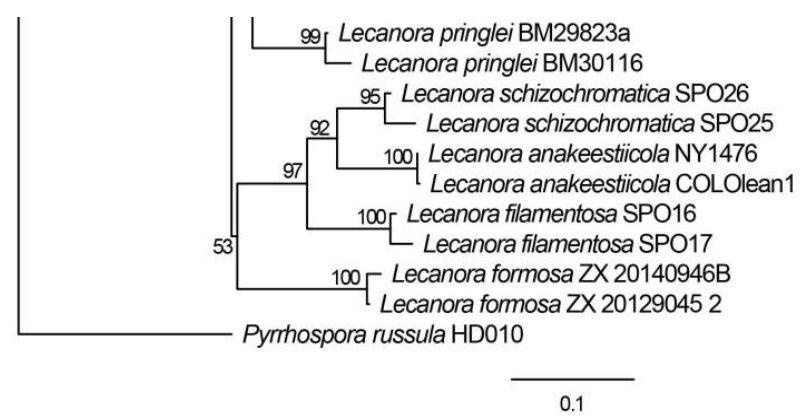

Fig. 1 - Phylogram generated from a maximum likelihood analysis based on ITS sequence data. The newly generated nucleotide sequences were compared against the GenBank (http://www.ncbi.nlm.nih.gov/) database using the Mega BLAST program. Related sequences were obtained from GenBank. One hundred eighty-three strains were included in the sequence analyses, which comprised 520 characters including gaps. Pyrrhospora russula HD010 was used as the outgroup. The best scoring RAxML tree with a final likelihood value of - 18905.396231 is presented. The matrix had 428 distinct alignment patterns, with $10.44 \%$ of undetermined characters or gaps. Estimated base frequencies were as follows; $\mathrm{A}=0.208, \mathrm{C}=0.288, \mathrm{G}=0.267, \mathrm{~T}=0.237$; substitution rates $\mathrm{AC}=1.262220, \mathrm{AG}=2.901173, \mathrm{AT}=1.748959, \mathrm{CG}=1.038279, \mathrm{CT}=$ 5.713006, GT $=1.000000$; gamma distribution shape parameter $\alpha=0.507732$. Bootstrap support values for ML equal or greater than $50 \%$ are given above the nodes. Newly generated sequences in blue.

\section{Pyrrhospora}

The genus Pyrrhospora was introduced by Körber (1855). Currently this genus includes around 30 species (Jaklitsch et al. 2016, Wijayawardene et al. 2017). Taxa are widespread and characterised by a crustose thallus, red-orange, red or red-brown apothecia and subglobose to clavate asci and simple hyaline ascospores (Hafellner 1984, 1993).

Pyrrhospora russula (Ach.) Hafellner, in Kalb \& Hafellner, Herzogia 9(1-2): 86 (1992)

Fig. 4

= Ramboldia russula (Ach.) Kalb, Lumbsch \& Elix, Nova Hedwigia 86 (1-2): 37 (2008)

Facesoffungi number: FoF05801

Lichenized on dead stem. Thallus: crustose, grey to green, granulose, rimose. Sexual morph: Apothecia $0.8-1.5 \mathrm{~mm}$ diam., arising singly or in small groups, sessile, slightly erumpent from the thallus, pulvinate, roundish or irregular, reddish orange. Hypothecium flat. Margins concolorous to receptacle. Hymenium hyaline to orangish, within a thick gelatinous matrix, turned reddish in $\mathrm{KOH}$. Epithecium branched and pigmented paraphyses apices form clearly distinguished epithecium above the hymenium, yellowish and turned red in KOH. Excipulum 60-100 $\mu \mathrm{m}$ at flanks, composed of loosely arranged hyphae without algal cells, outer cells are orangish, inner cells are hyaline. Paraphyses 1.2-1.8 $\mu \mathrm{m}$ wide, numerous, filiform, apically branched, septate. Asci $25-35 \times$ 8-12 $\mu \mathrm{m}, 8$-spored, clavate to subglobose, narrowed to base, short pedicellate, rounded at the apex, amyloid ring absent at the ascus apex. Ascospores 6-10 $\times 2-3 \mu \mathrm{m}$, hyaline, smooth-walled, ellipsoid. Asexual morph: Undetermined.

Material examined - Thailand, Chiang Rai Province, Mae Fah Luang University, on dead stems, 22 May 2015, A.H. Ekanayaka, HD010 (MFLU 16-0575).

GenBank accessions - ITS-MK499340

Notes - Our molecular data clearly indicates that our new strain of MFLU 16-0575 which was collected on a dead stem from Thailand, is monophyletic with Pyrrhospora russula in the ITS matrix (Fig. 3). The Pyrrhospora russula clade of these two strains is supported by $98 \%$ bootstrap support and their ITS sequence data are similar by $96 \%$. This identification is supported by it having orange-red to bright red apothecia, a reddish hymenium and ellipsoid ascospores as in the description provided by Gumboski (2014). However ascospores of previous collection from Brazil are slightly larger $(8-12 \times 3-4 \mu \mathrm{m})$ than our collection (Gumboski 2014). Moreover, P. laeta is 
morphologically similar to $P$. russula, but $P$. russula differs in having highly branched apices to the paraphyses (Kalb \& Hafellner 1992). This species is known from America, Africa and Asia (Gumboski 2014). The generally large differences in base pairs warrants further investigation of what appears to be a species complex.

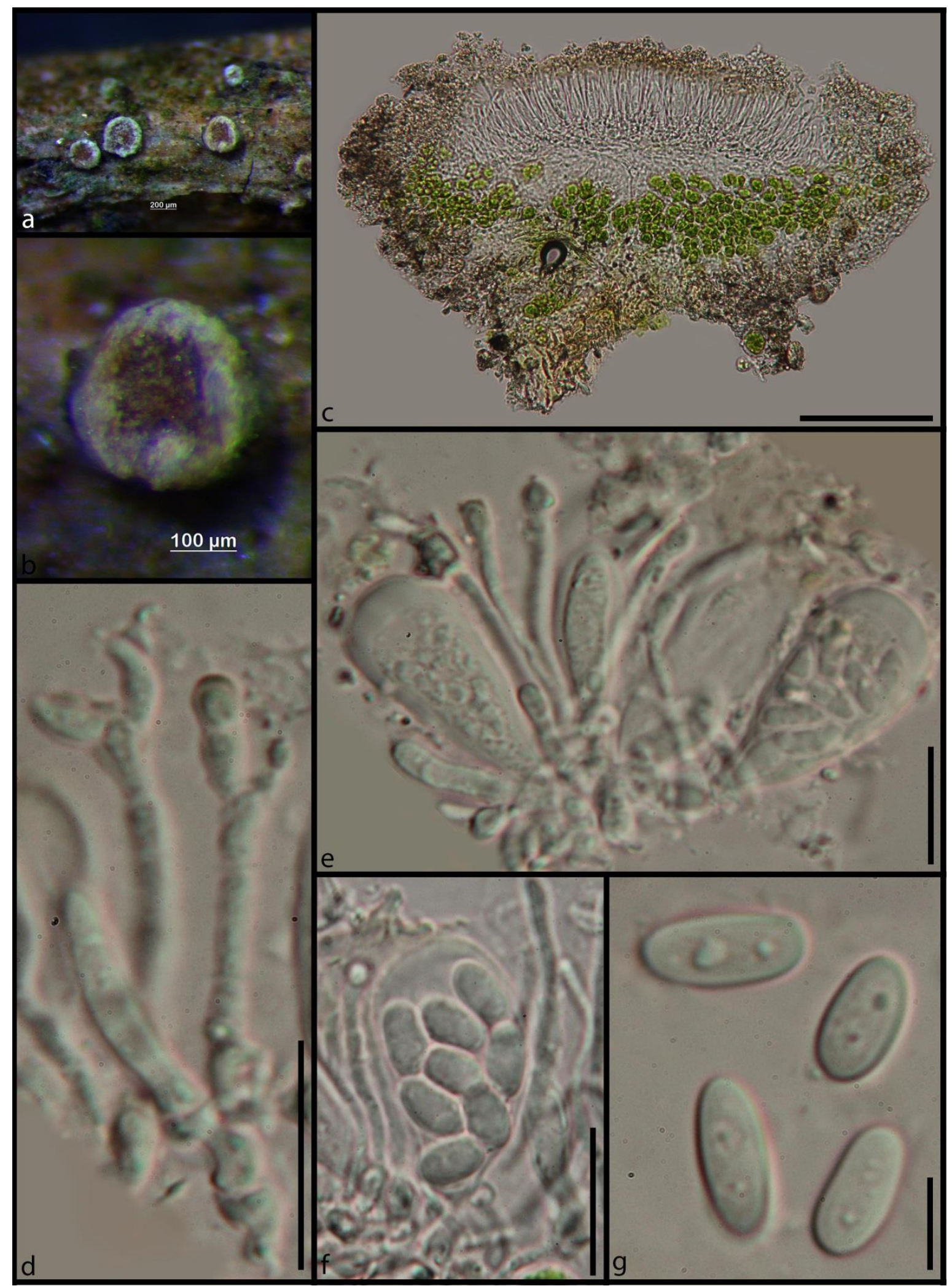

Fig. 2 - Morphology of Lecanora hagenii (MFLU 16-0605). a, b Ascomata on wood. c Cross section of an ascoma. d Apically branched paraphyses. e, f Asci and paraphyses. g Ellipsoid ascospores. Scale bars: $\mathrm{c}=100 \mu \mathrm{m}, \mathrm{d}, \mathrm{e}, \mathrm{f}=15 \mu \mathrm{m}, \mathrm{g}=10 \mu \mathrm{m}$. 


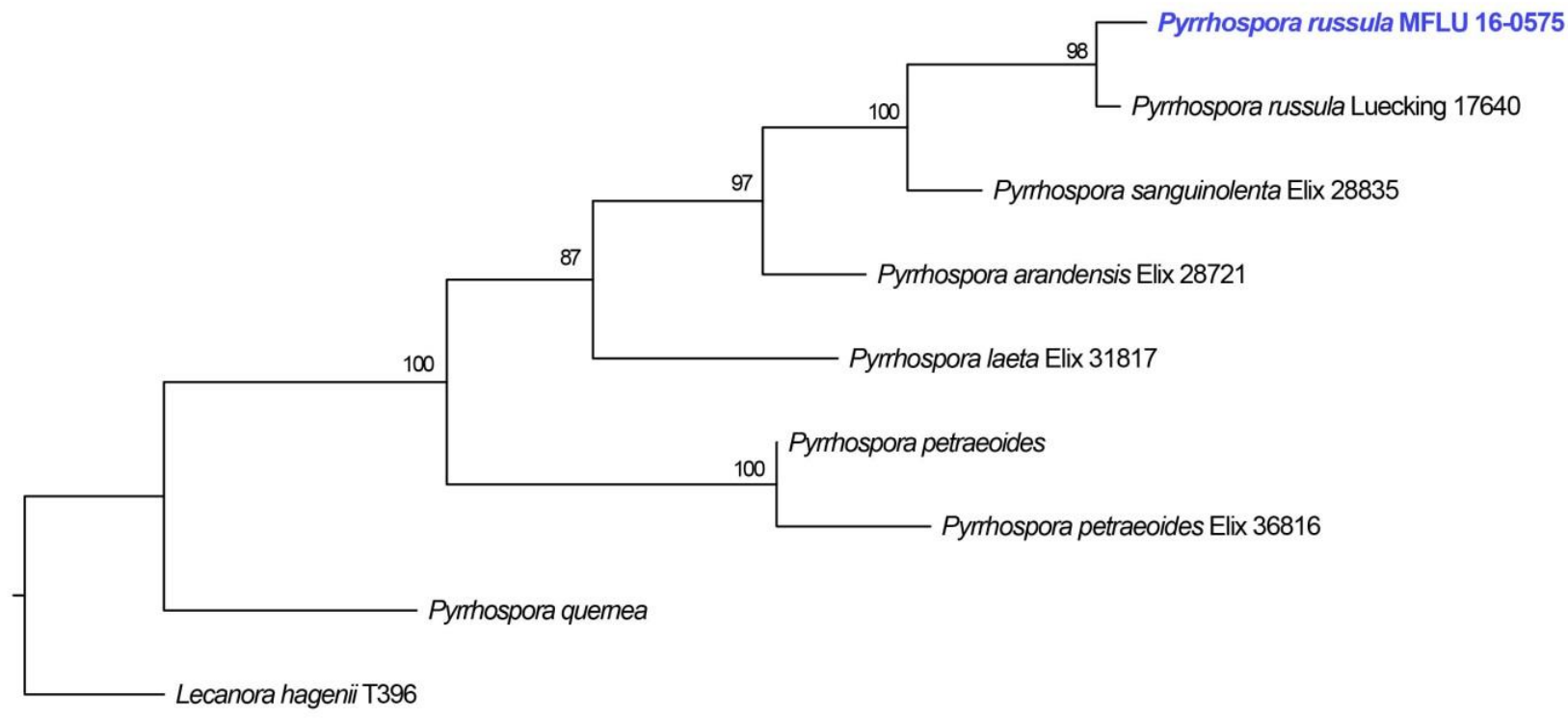

0.05

Fig. 3 - Phylogram generated from a maximum likelihood analysis based on ITS sequence data. The newly generated nucleotide sequences were compared against the GenBank (http://www.ncbi.nlm.nih.gov/) database using the Mega BLAST program. Related sequences were obtained from GenBank. Nine strains were included in the sequence analyses, which comprised 577 characters including gaps. Lecanora hagenii T396 was used as outgroup. The best scoring RAxML tree with a final likelihood value of - 2238.014137 is presented. The matrix had 234 distinct alignment patterns, with $23.30 \%$ of undetermined characters or gaps. Estimated base frequencies were as follows; $\mathrm{A}=0.226861, \mathrm{C}=0.261569, \mathrm{G}=0.263330, \mathrm{~T}=0.248239$; substitution rates $\mathrm{AC}=1.869257, \mathrm{AG}=2.913060, \mathrm{AT}=2.236712, \mathrm{CG}=1.121586, \mathrm{CT}=$ 4.791254, GT $=1.000000$; gamma distribution shape parameter $\alpha=1.381352$. Bootstrap support values for ML equal or greater than $50 \%$ are given above the nodes. Newly generated sequences in blue.

\section{Malmideaceae}

The family Malmideaceae was introduced by Kalb et al. (2011) to accommodate the Lecidea piperis- and Lecanora granifera groups. Currently this family includes five genera.

\section{Malmidea}

The genus Malmidea was established by Kalb et al. (2011). Currently this genus comprises 55 species (Joseph et al. 2018). The taxa are widely distributed and characterized by a crustose thallus, biatorine apothecia, asci without tubular structure, filiform paraphyses and simple ascospores (Joseph et al. 2018, Weerakoon et al. 2016, Kalb et al. 2011).

Malmidea subaurigera (Vain.) Kalb, Rivas Plata \& Lumbsch, in Kalb, Rivas Plata, Lücking \& Lumbsch, Biblthca Lichenol.106: 161 (2011)

Fig. 6

Facesoffungi number: FoF05802

Lichenized on dead stem. Thallus: crustose, grey to green, turning orangish in $\mathrm{KOH}$, granulose, rimose. Sexual morph: apothecia $0.2-0.7 \mathrm{~mm}$ wide, arising singly, sessile, slightly erumpent from the substrate, pulvinate, chocolate brown to grey-brown with clear thalline margins. Hypothecium convex. Hymenium hyaline, within a thick gelatinous matrix. Excipulum 50-60 $\mu \mathrm{m}$ wide, composed of black pigmented cells of textura intricata. Paraphyses $1.3-1.8 \mu \mathrm{m}$ wide at the apex $(\bar{x}=1.5 \mu m, \mathrm{n}=20)$, numerous, filiform, aseptate, slightly branched. Asci $45-65 \times 12-18 \mu \mathrm{m}$ $(\bar{x}=52 \times 14 \mu \mathrm{m}, \mathrm{n}=30) 8$-spored, narrowed to base, short stipitate, cylindric-clavate, rounded at 
the apex. Ascospores 12-15 $\times 6-7 \mu m(\bar{x}=14 \times 6.3 \mu m, \mathrm{n}=40)$, hyaline, smooth walled, ellipsoid to fusoid, aseptate, guttulate. Asexual morph: Undetermined.

Material examined - Thailand, Chiang Rai Province, Rong Kwang, Phrae, on dead bark, 10 January 2018, A. H. Ekanayaka, HD079 (MFLU 18-0692, HKAS 104265).

GenBank accessions - ITS-MK499341, LSU-MK499354

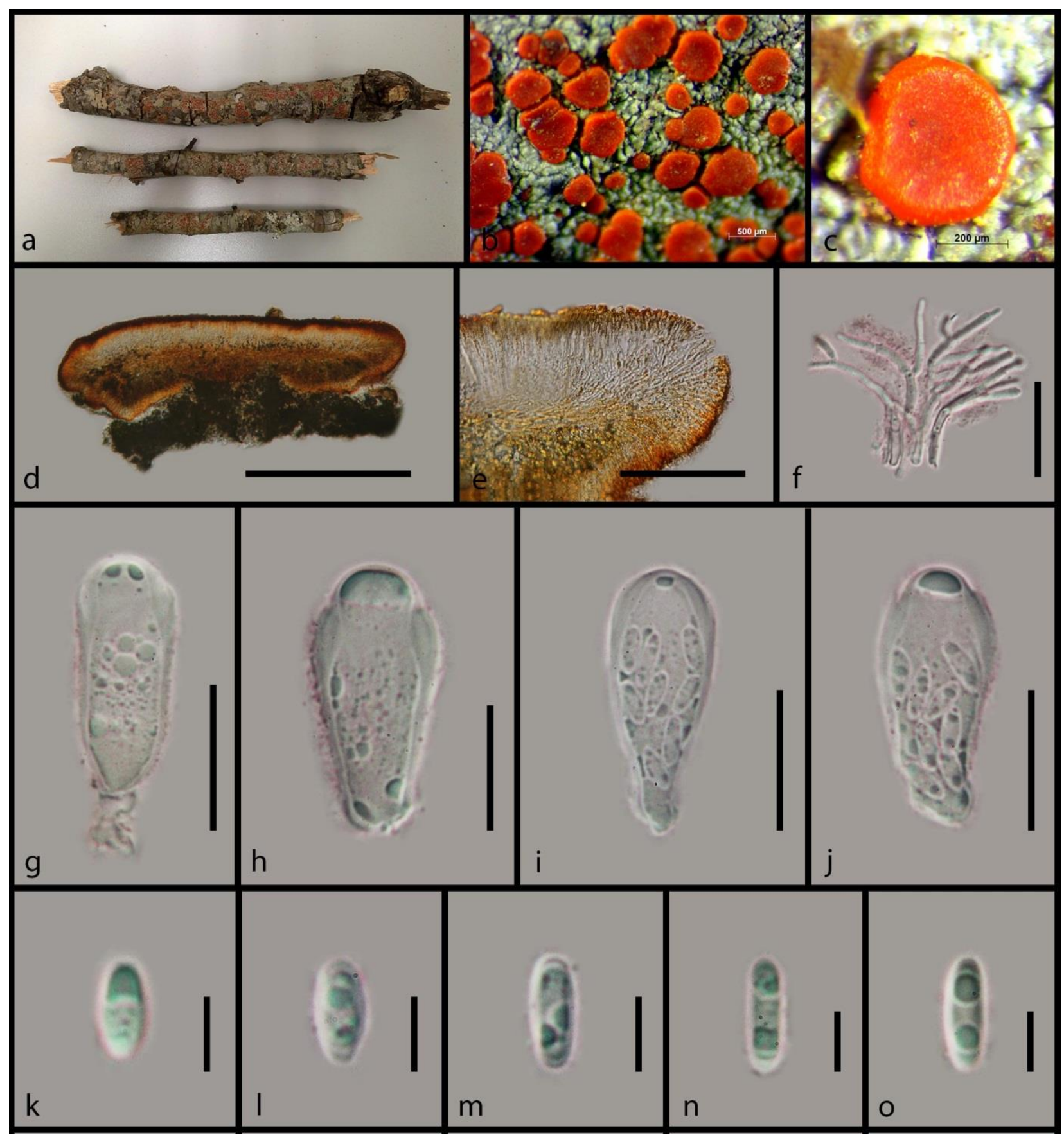

Fig. 4 - Morphology of Pyrrhospora russula (MFLU 16-0575). a Substrate. b, c Ascomata on wood. d Cross section of an ascoma. e Close up of a vertical section of the ascoma at margin. f Filiform paraphyses. g-j Short pedicellate asci. k-o Ovate ascospores. Scale bars: $d=400 \mu \mathrm{m}$, $\mathrm{e}=100 \mu \mathrm{m}, \mathrm{f}=20 \mu \mathrm{m}, \mathrm{g}-\mathrm{j}=15 \mu \mathrm{m}, \mathrm{k}-\mathrm{o}=5 \mu \mathrm{m}$.

Notes - Our collection from Thailand clustered within Malmidea close to M. floridensis and M. ееииае (Fig. 5). The new collection formed an independent clade with high bootstrap support (92\%). LSU sequence data of this species differs by 20 base pairs from $M$. floridensis and 21 base pairs from M. ееииае. Morphologically of our new collection is similar to the description of 
Malmidea subaurigera by Kalb et al. (2011), except in having slightly smaller asci. Malmidea subaurigera is morphologically similar to M. aurigera, M. papillosa and M. granifera, but $M$. aurigera has a yellow thallus and $M$. papillosa and $M$. granifera have larger ascospores (Weerakoon et al. 2016, Kalb et al. 2011). This species was previously recorded from Thailand by Kalb et al. (2011). LSU sequence data of M. subaurigera was not available in GenBank for comparison with our collection, but the Thai collections need further consideration.

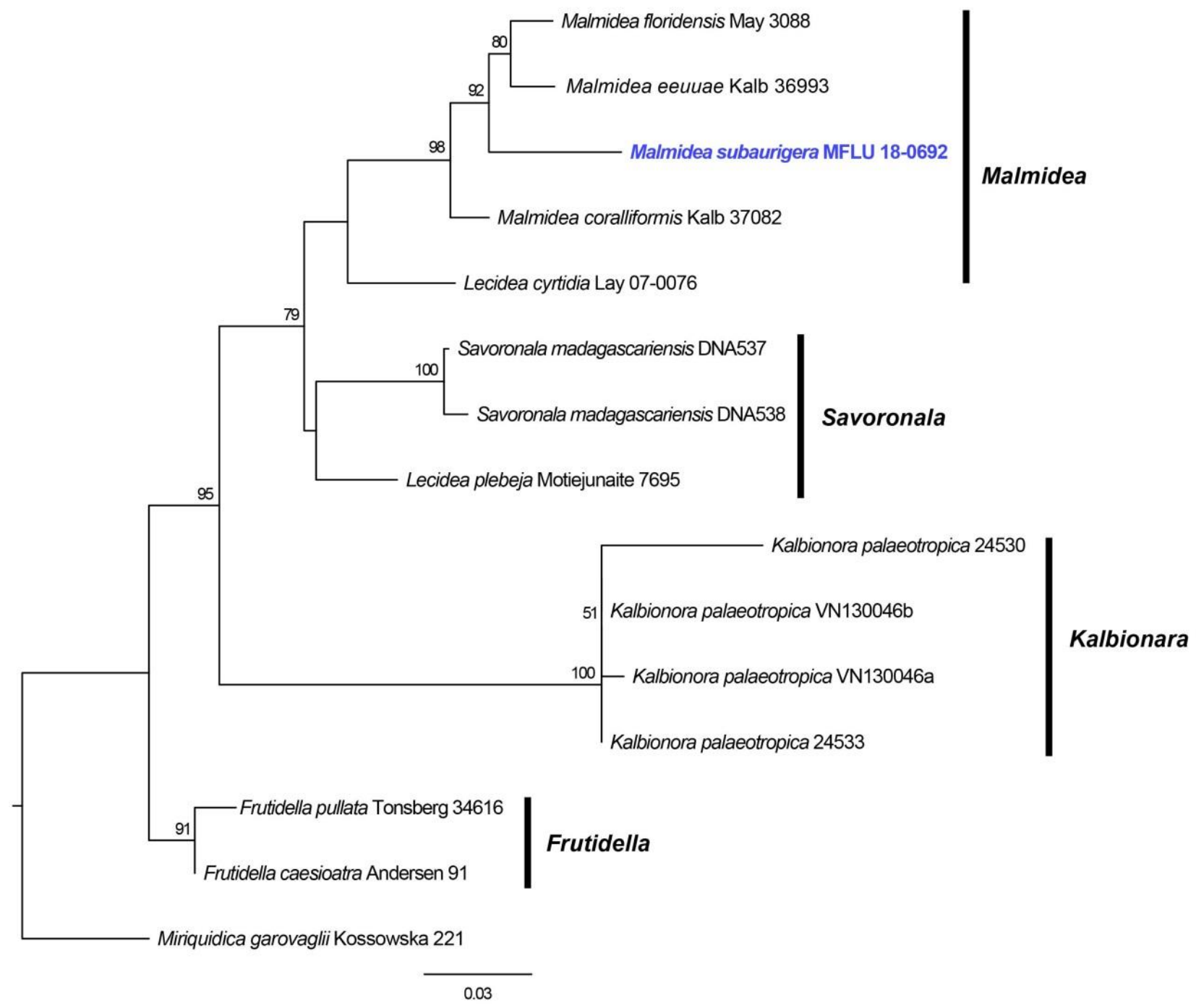

Fig. 5 - Phylogram generated from a maximum likelihood analysis based on LSU sequence data. The newly generated nucleotide sequences were compared against the GenBank (http://www.ncbi.nlm.nih.gov/) database using the Mega BLAST program. Related sequences were obtained from GenBank. Fifteen strains were included in the sequence analyses, which comprised 802 characters including gaps. Miriquidica garovaglii was used as the outgroup. The best scoring RAxML tree with a final likelihood value of 2902.279588 is presented. The matrix had 237 distinct alignment patterns, with $14.10 \%$ of undetermined characters or gaps. Estimated base frequencies were as follows; $\mathrm{A}=0.254, \mathrm{C}=0.228, \mathrm{G}=0.308, \mathrm{~T}=0.210$; substitution rates $\mathrm{AC}=1.402567$, $\mathrm{AG}=2.713112, \mathrm{AT}=1.430805, \mathrm{CG}=1.070071, \mathrm{CT}=8.095518, \mathrm{GT}=1.000000 ;$ gamma distribution shape parameter $\alpha=0.507684$. Bootstrap support values for ML equal or greater than $50 \%$ are given above the nodes. Newly generated sequence in blue.

\section{Ramalinaceae}

The family was introduced by Agardh (1821). Taxa are lichenized or rarely lichenicolous and characterised by crustose or squamulose to fruticose thallus with chlorococcoid photobiont, 
apothecial ascomata, hamathecium consisting of often branched paraphyses, 8-spored, semifissitunicate, amyloid asci and ellipsoid to oblong or cylindrical, hyaline ascospores (Jaklitsch et al. 2016).

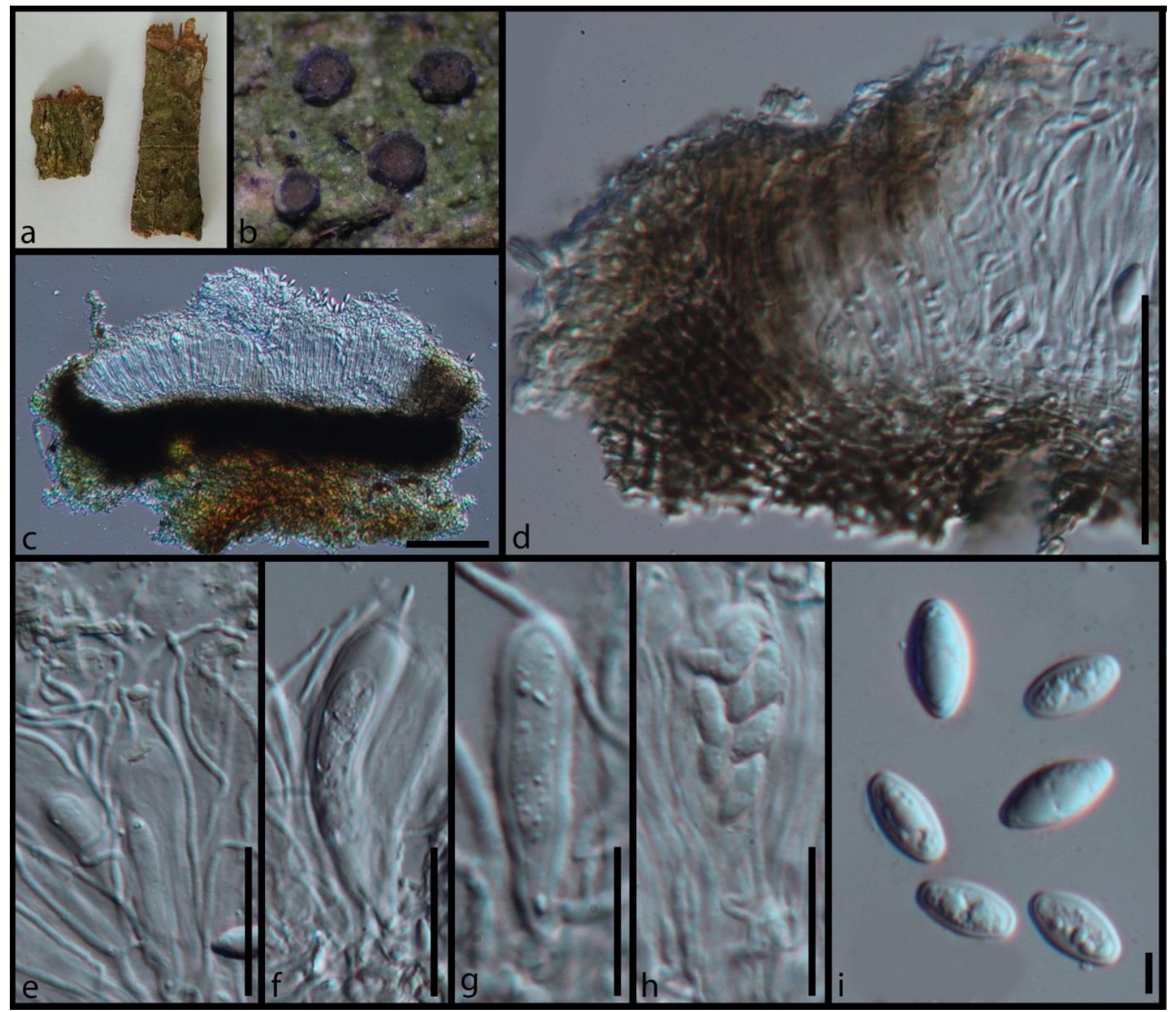

Fig. 6 - Morphology of Malmidea subaurigera (MFLU 18-0692). a Substrate. b Ascomata on wood. c Cross section of an ascoma. d Close up of the excipulum at margins and flanks. e Aseptate paraphyses. f-h Short pedicellate asci. i Ellipsoid to fusoid ascospores. Scale bars: $c=100 \mu \mathrm{m}, \mathrm{d}=$ $50 \mu \mathrm{m}, \mathrm{e}-\mathrm{h}=25 \mu \mathrm{m}, \mathrm{i}=5 \mu \mathrm{m}$.

\section{Bacidia}

The genus Bacidia was introduced by De Notaris (1846) and currently includes over 230 species (Jaklitsch et al. 2016, Wijayawardene et al. 2017). Taxa are characterized by a crustose thallus, sessile biatorine or lecideine apothecia with short stalk, with elongate-clavate asci, and hyaline, transversely multiseptate ascospores (Hafellner 1984).

Bacidia subareolata Ekanayaka \& K.D. Hyde, sp. nov.

Fig. 8 Index Fungorum number: IF556241; Facesoffungi number: FoF05803

Etymology - refers to the similarity to Bacidia areolata

Holotype - MFLU 18-1817

Lichenized on dead stem. Thallus: crustose, brown to green, areolate, cracked, wrinkled. Sexual morph: Apothecia $0.5-1.5 \mathrm{~mm}$ diam., arising singly or in small groups, sessile, slightly 
erumpent from the substrate, pulvinate apothecia, light brown to dark brown. Hypothecium convex. Discs light brown to dark brown and sometimes black. Margins light brown-dark brown to black. Hymenium hyaline, presence with in a thick gelatinous matrix. Excipulum 50-120 $\mu \mathrm{m}$ wide, outer layer composed of small, thin-walled, orange brown colour cells of textura angularis-globulosa and inner layer composed of narrow, long, thin-walled, hyaline cells of textura intricata. Hymenium hyaline. Epithecium branched paraphyses apices glued together to form clearly distinguishing epithecium above the hymenium, brownish. Paraphyses $1.2-1.9 \mu \mathrm{m}$ wide $(\bar{x}=1.6 \mu \mathrm{m}, \mathrm{n}=20)$, numerous, filiform, propoloid, septate, little branched at the apex. Asci 52-59 $\times 9-11 \mu \mathrm{m}(\bar{x}=55.9$ $\times 9.8 \mu \mathrm{m}, \mathrm{n}=30) 8$-spored, narrowed short pedicellate, cylindric-clavate, rounded at the apex, croziers present at the base of asci. Ascospores 30-50 × 2.7-3.4 $\mu \mathrm{m}(\bar{x}=40.2 \times 3.0 \mu \mathrm{m}, \mathrm{n}=40)$, arranged as a short fascicle, hyaline, smooth walled, filiform, narrowed to the base, 7-10- septate. Asexual morph: Undetermined.

Material examined - Thailand, Chiang Rai Province, Mae Fah Luang University, on dead bark, 25 December 2014, A.H. Ekanayaka, HD 006 (MFLU 18-1817).

GenBank accessions - ITS-MK499342

Notes - Our new collection from Thailand grouped basal to the Bacidia areolata and Bacidia suffusa group, especially close to Bacidia areolata (Fig. 7) with high bootstrap support (92\%). ITS data of our new collection differs from that of Bacidia areolata by 36 base pairs out of $470(10 \%)$ and therefore is a new species based on the guidelines of Jeewon \& Hyde (2016). Our species is similar to the description of Bacidia millegrana by Awasthi \& Mathur (1987), but Bacidia millegrana differs in having 10-19-septate ascospores. The Bacidia species, B. subareolata, B. campalea, B. areolata and $B$. suffusa form a monophyletic group and are characterized by peachcoloured or brown apothecia, cylindrical or clavate, 8-spored asci and multi-septate filiform ascospores. However, B. subareolata differs from these taxa in having slightly smaller ascospores and apically branched paraphyses (Gerasimova et al. 2018).

\section{Caliciales}

This order was established by Bessey in 1907, and reported from various habitats (Ekanayaka et al. 2017, Jaklitsch et al. 2016). The order is not easily characterized morphologically and includes both mazaediate and non-mazaediate genera of both crustose, fruticose and foliose genera.

\section{Caliciaceae}

This family was established by Chevallier (1826) with lichenized and lichenicolous species. Currently Caliciaceae comprises around 29 genera and 630 species (Jaklitsch et al. 2016). Taxa form crustose to squamulose, foliose, or fruticose lichen thalli. Ascomata are characterized by having mazediate to non-mazaediate, stalked to sessile, mostly lecideine and rarely lecanorine, blackish apothecia. The excipulum is composed of proso- or paraplectenchymatous cells. The outer excipulum cells are usually dark brown, while the inner cells are hyaline. Paraphyses are unbranched or slightly branched and amyloid. Asci are mostly semifissitunicate and amyloid, but in some genera prototunicate. Ascospores are septate (1-3-septate), muriform to ellipsoid (Jaklitsch et al. 2016, Prieto \& Wedin 2016). Some taxa produce secondary metabolites such as terpenes, depsidones (e.g., norstictic acid), lichexanthone, and sometimes anthraquinones e.g., in a pigmented medulla (Jaklitsch et al. 2016). Species are widely distributed in temperate, subtropical, and tropical regions specially on bark, rocks and wood (Jaklitsch et al. 2016).

\section{Buellia}

The lichen genus Buellia was introduced by De Notaris (1846) and currently includes around 400 species (Jaklitsch et al. 2016). The genus is characterized by black lecideine apothecia, septate, oblong to ellipsoid, rarely citriform, hyaline to brownish ascospores and deep reddish-brown to yellow or yellowish greed to rarely hyaline hypothecium (Joshi et al. 2010). 


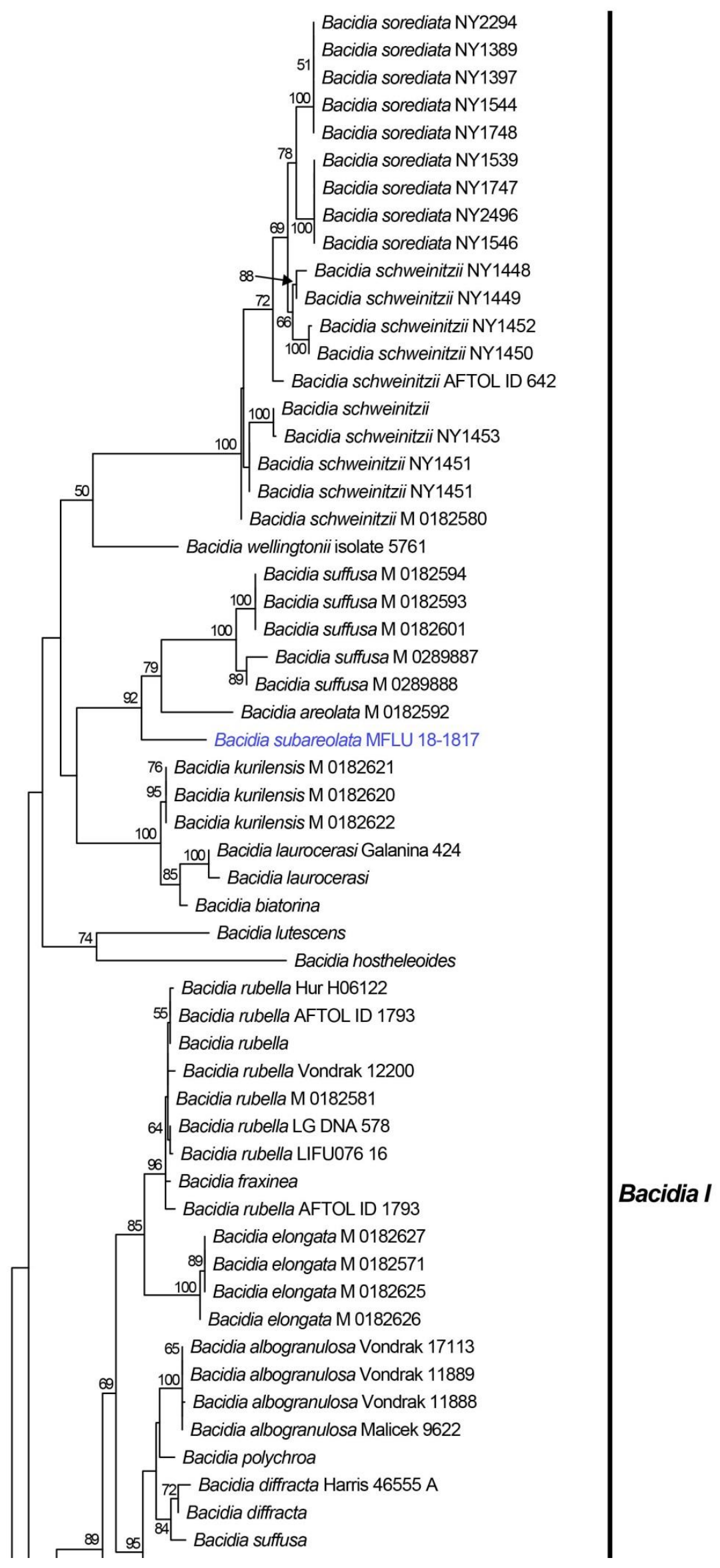




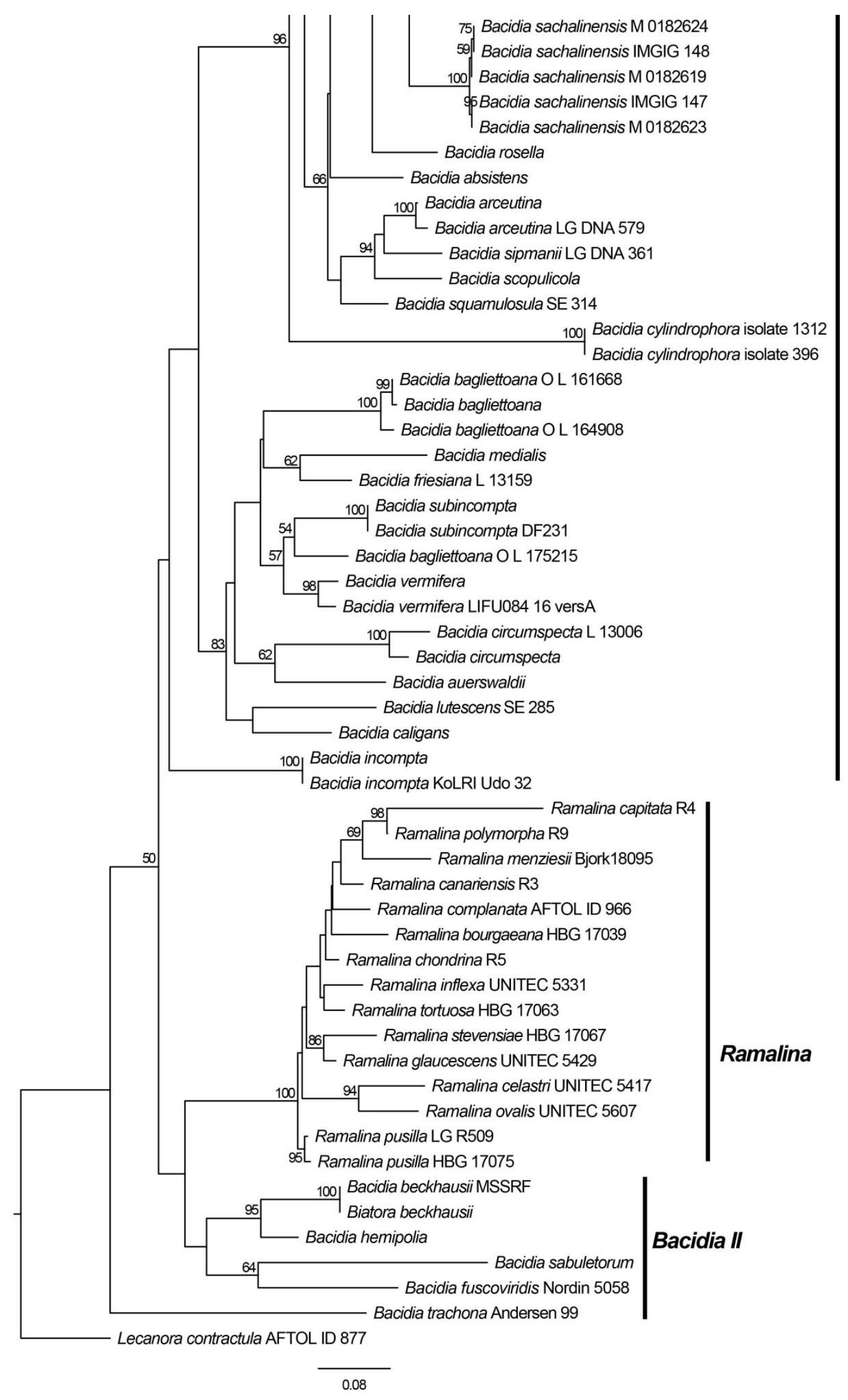

Fig. 7 - Phylogram generated from a maximum likelihood analysis based on ITS sequence data. The newly generated nucleotide sequences were compared against the GenBank (http://www.ncbi.nlm.nih.gov/) database using the Mega BLAST program. Related sequences were obtained from GenBank. One hundred-nine strains were included in the sequence analyses, which comprised 542 characters including gaps. Lecanora contractula AFTOL ID 877 was used as 
outgroup. The best scoring RAxML tree with a final likelihood value of 10118.852902 is presented. The matrix had 403 distinct alignment patterns, with $15.34 \%$ of undetermined characters or gaps. Estimated base frequencies were as follows; $\mathrm{A}=0.226, \mathrm{C}=0.280, \mathrm{G}=0.255, \mathrm{~T}=0.239$; substitution rates $\mathrm{AC}=2.548301, \mathrm{AG}=3.430051, \mathrm{AT}=3.191893, \mathrm{CG}=1.232417, \mathrm{CT}=$ 7.027845, GT $=1.000000$; gamma distribution shape parameter $\alpha=0.525788$. Bootstrap support values for ML equal or greater than $50 \%$ are given above the nodes. Newly generated sequence in blue.

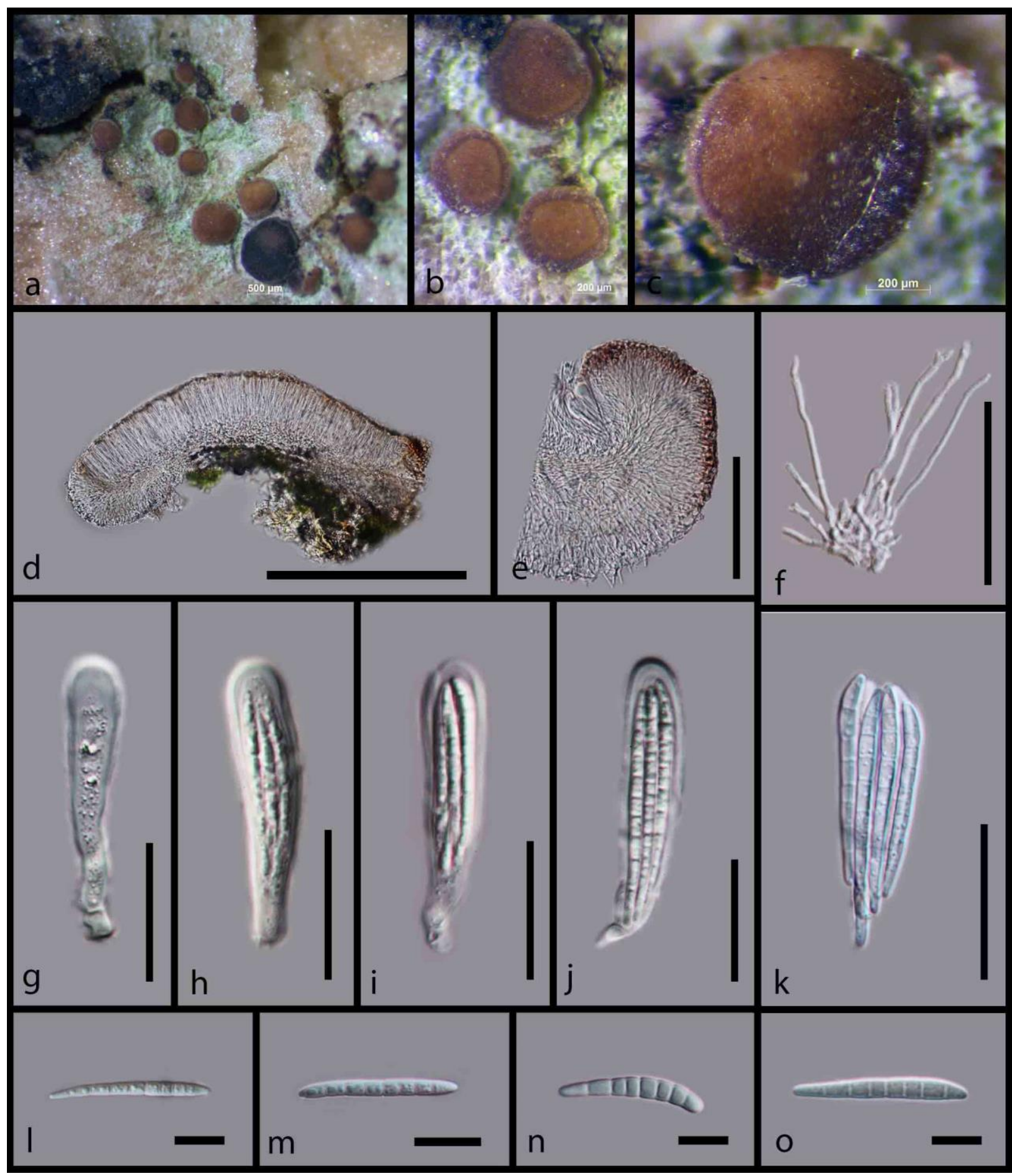

Fig. 8 - Morphology of Bacidia subareolata (holotype MFLU 18-1817). a, b Ascomata on wood. c Ascoma on wood. d Cross section of an ascoma. e Close up of a vertical section of the ascoma at margin. f Septate paraphyses. g-j Short pedicellate asci. k Short fascicle of ascospores. 1-o Cylindric ascospores. Scale bars: $\mathrm{a}=500 \mu \mathrm{m}, \mathrm{b}=200 \mu \mathrm{m}, \mathrm{c}=200 \mu \mathrm{m}, \mathrm{d}=300 \mu \mathrm{m}, \mathrm{e}=100 \mu \mathrm{m}, \mathrm{f}=40 \mu \mathrm{m}$, $\mathrm{g}-\mathrm{k}=25 \mu \mathrm{m}, 1-\mathrm{o}=10 \mu \mathrm{m}$. 
Buellia sublauri-cassiae Ekanayaka \& K.D. Hyde, sp. nov.

Fig. 10

Index Fungorum number: IF556242; Facesoffungi number: FoF05804

Etymology - refers to the similarity to Buellia lauricassiae

Holotype - MFLU 18-0672

Lichenized on dead stem. Thallus: crustose, yellowish to grey, granulose, rimose. Sexual morph: Apothecia 400-800 $\mathrm{mm}$ diam., arising singly or in small groups, sessile, slightly erumpent from the thallus, pulvinate, roundish or irregular, black. Hypothecium convex. Disc smooth to slightly granulose, black. Margins distinct, black. Hymenium hyaline, within a thick gelatinous matrix. Epithecium branched, swollen and pigmented paraphyses apices form clearly distinguishing pseudo epithecium above the hymenium, brown. Excipulum 40-50 $\mu \mathrm{m}$ at flanks, composed of small, thin-walled, cells of textura intricata without algal cells, inner cells are hyaline to brownish, outer cells are brown, with orange pigments. Paraphyses $1.2-1.8 \mu \mathrm{m}$ wide at the middle $(\bar{x}=1.4$ $\mu \mathrm{m}, \mathrm{n}=20), 2-4.5 \mu \mathrm{m}$ wide at the tip $(\bar{x}=3.2 \mu \mathrm{m}, \mathrm{n}=20)$, numerous, filiform, propoloid, aseptate, branched, swollen and pigmented at the apices. Asci 50-75 × 10-20 $\mu \mathrm{m}(\bar{x}=60 \times 15 \mu \mathrm{m}$, $\mathrm{n}=30$ ) 8-spored, narrowed to base, short pedicel, cylindric-clavate, rounded at the apex, nonamyloid. Ascospore 15-20 × 7-9 $\mu m(\bar{x}=17 \times 8 \mu m, \mathrm{n}=40)$, greenish brown, smooth walled, ellipsoid, tear-shaped, lover cell is slightly wider than upper cell, lower apex rounded, upper apex slightly pointed to rounded. Asexual morph: Undetermined.

Material examined - Thailand, Chiang Rai Province, Mae Fah Luang University, on dead stem, 28 June 2016, A.H. Ekanayaka HD04Y (MFLU 18-0672, holotype); same collections details (HKAS 104246, isotype); Thailand, Chiang Rai Province, Mae Fah Luang University, on dead stem, 12 November 2017, A.H. Ekanayaka HD064 (MFLU 18-0681, paratype)

GenBank accessions - ITS: MFLU 18-0672- MK499343, MFLU 18-0681- MK499344; LSU: MFLU 18-0672- MK499355, MFLU 18-0681- MK499356

Notes - Our new collection from Thailand clustered with Buellia with high (100\%) bootstrap support (Fig. 9). Phylogenetically Buellia sublauri-cassiae groups with Buellia lauri-cassiae with high statistical support (100\%), but differs by 54 base pairs (ITS) from Buellia lauri-cassiae. Moreover, Buellia sublauri-cassiae differs from Buellia lauri-cassiae by having 1-septate ascospores (Watanuki et al. 2017). Morphological characters of our collection are similar to Buellia halonia (Bungartz et al. 2004), but differ in not having areolate greenish thallus black in outline.

Buellia polyspora (Willey) Vain., Acta Soc. Fauna Fl. Fenn. 7: 171 (1890) Fig. 11 三Amandinea polyspora (Willey) E. Lay \& P.F. May, in Sheard \& May, Bryologist 100(2): 164 (1997)

三 Buellia myriocarpa var. polyspora Willey, in Tuckerman, Syn. N. Amer. Lich. (Boston) 2: 97 (1888)

Facesoffungi number: FoF05805

Lichenized on dead stem. Thallus: crustose, greenish, granulose. Sexual morph: Apothecia $0.8-1 \mathrm{~mm}$ wide, arising singly or in small groups, sessile, erumpent from the substrate, turbinate, black when fresh. Hypothecium convex, disc and the margins are black when fresh. Hymenium hyaline, enclosed in a thick gelatinous matrix. Epithecium branched, slightly swollen and pigmented paraphyses apices form clearly distinguishing pseudo epithecium above the hymenium, greenish brown. Excipulum 36-45 $\mu \mathrm{m}(\bar{x}=32.3 \mu \mathrm{m}, \mathrm{n}=10)$ outer cells are textura angularis to globulosa inner layer composed of hyaline loosely arranged hyphae. Paraphyses 1.5-2 $\mu \mathrm{m}$ wide ( $\bar{x}$ $=1.7 \mu \mathrm{m}, \mathrm{n}=20$ ), numerous, filiform, slightly swollen at the apex and dark greenish brown pigmented that is dissolved in KOH. Asci $42-48 \times 10-15 \mu \mathrm{m}(\bar{x}=45.1 \times 13.1 \mu \mathrm{m}, \mathrm{n}=30) 16-$ spored, short sessile, cylindric-clavate, rounded at the apex. Ascospores 17-21 $\times 4-7 \mu m(\bar{x}=18 \times$ $6 \mu \mathrm{m}, \mathrm{n}=40$ ), multiseriate, ellipsoid, one septate, immature ascospores are hyaline or light brown guttulate, matured spores are green or dark brown and guttulate, thin walled. Asexual morph: Undetermined.

Material examined - Thailand, Chiang Rai Province, Chiang sen, on dead stems, 24 June 2015, A.H. Ekanayaka, HD069, HD71 (MFLU 18-0685, MFLU 18-0687). 
GenBank accessions - ITS: MFLU 18-0685-MK499345, MFLU 18-0687-MK499346; LSU: MFLU 18-0685-MK499357, MFLU 18-0687-MK499358

Notes - Buellia polyspora is characterized by its small spores and polysporous asci, which mostly have 16 spores and occasionally 8 or 32 spores (Bungartz et al. 2007). Our new strain from Thailand is morphologically similar to the description of Buellia polyspora by Bungartz et al. (2007). Moreover, Buellia polyspora phylogenetically and morphologically is close to B. schaereri (Fig. 9). Bungartz et al. (2007) discussed the morphological similarities between B. schaereri and $B$. polyspora, but $B$. schaereri differs in having 8-spored asci as opposed to 16 in our collection (Bungartz et al. 2007). Joshi et al. (2010) and Bungartz et al. (2007) recorded presence of pycnidial conidiomata with filiform conidia within Buellia polyspora. However in our collection we did not observe the asexual morph.

The genus Amandinea was segregated from Buellia and is characterized by apothecial ascomata, crustose and squamulose thalli and filiform and curved conidia (Scheidegger 1993, Sheard \& May 1997). Sheard \& May (1997) introduced the combination Amandinea polyspora and placed Buellia myriocarpa var. polyspora and Buellia polyspora within it based on their filiform conidia. Later, Bungartz et al. (2007) re-established Buellia polyspora and synonymized Amandinea polyspora under Buellia polyspora. Bungartz et al. (2007) however, suggested that B. polyspora may belong to a smaller core group within Amandinea, by considering the morphological similarities between the type species of Amandinea; $A$. coniops $(=B$. coniops $)$ and B. polyspora [i.e. presence of sessile black apothecia, ascospore morphology and filiform conidia (Sheard \& May 1997)]. However, according to the present phylogenetic analysis and previous literature, the genus Amandinea is currently not well-supported, while the genus Buellia is highly polyphyletic (Bungartz et al. 2007).

Considering the confused status of this species, and the fact this is the first molecular record, we have decided to use the older name Buellia polyspora until further collections are made and sequenced (Bungartz et al. 2007). Furthermore, to stabilize the phylogeny of the genera Buellia and Amandinea, wider sampling, sequencing and wider range of genetic markers are required.

\section{Physciaceae}

The family Physciaceae was introduced by Engler (1898) and currently includes 14 genera (Jaklitsch et al. 2016). Taxa are widely distributed and characterized by crustose to squamulose, foliose, or sub-fruticose thallus with Trebouxia photobiont, ascomata apothecial, hamathecium consisting of slightly capitate paraphyses, semifissitunicate asci, ellipsoid, transversely septate ascospores (Elix 2011).

\section{Rinodina}

The genus was introduced by Gray (1821) and includes around 300 species (Jaklitsch et al. 2016). Taxa are widely distributed and characterised by crustose to subsquamulose, rarely squamulose thallus, ascomata apothecial, asci (4-) 8-spored and olive-green or brown, ellipsoid ascospores (Elix 2011).

Rinodina pyrina (Ach.) Arnold, Flora (Regensburg) 64: 196 (1881)

Fig. 13

Facesoffungi number: FoF05806

Lichenized on dead stem. Thallus: crustose, greenish grey, granulose. Sexual morph: Apothecia $0.2-0.6 \mathrm{~mm}$ wide, arising singly or in small groups, sessile, erumpent from the substrate, cupulate, black when fresh. Hypothecium convex. Disc black. Margins green. Hymenium hyaline, enclosed in a thick gelatinous matrix. Epithecium slightly swollen paraphyses apices form pseudo epithecium above the hymenium, hyaline to brownish. Excipulum 30-50 $\mu \mathrm{m}$ outer cells are textura angularis to globulosa inner layer composed of hyaline loosely arranged hyphae. Paraphyses 2.2$2.8 \mu \mathrm{m}$ wide at the apex, numerous, filiform, slightly swollen at the apex, aseptate, slightly branched at the base. Asci $40-45 \times 10-15 \mu \mathrm{m}, 8$-spored, short sessile, cylindric-clavate, rounded at 


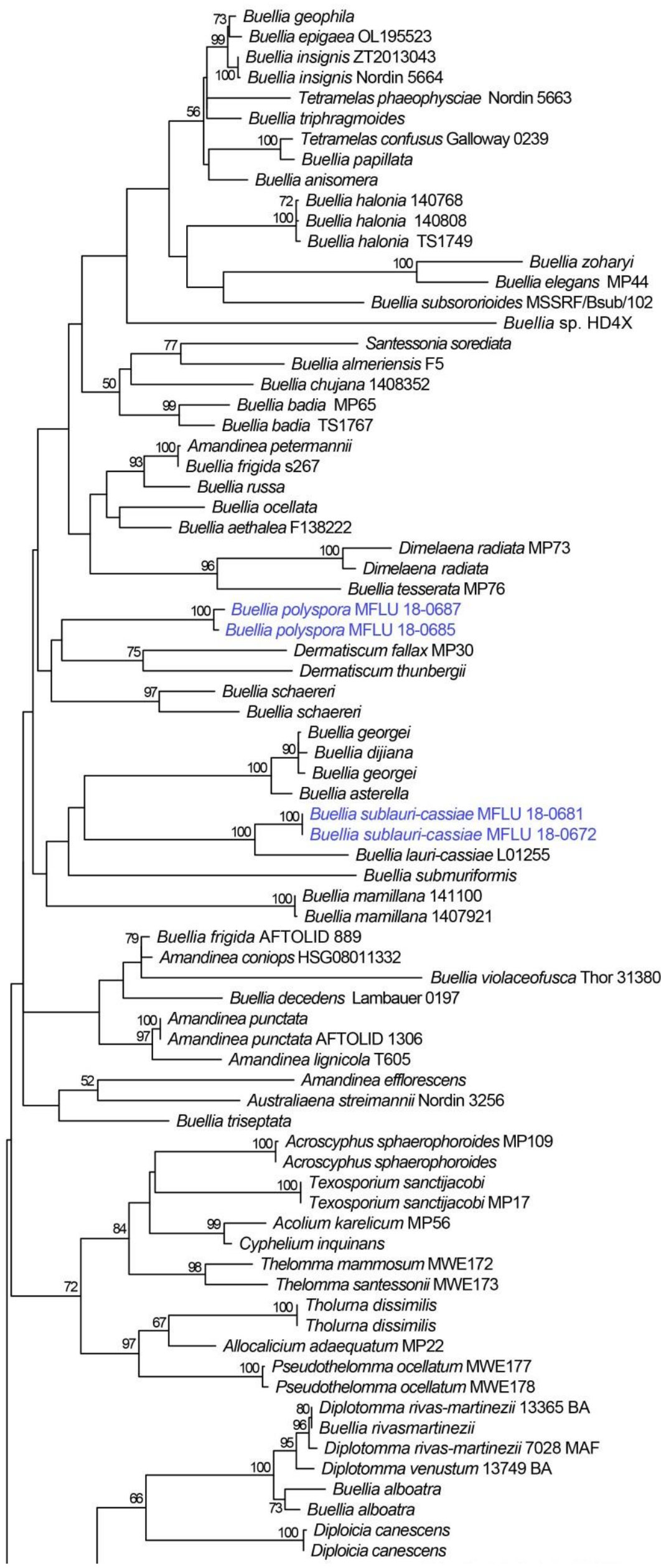




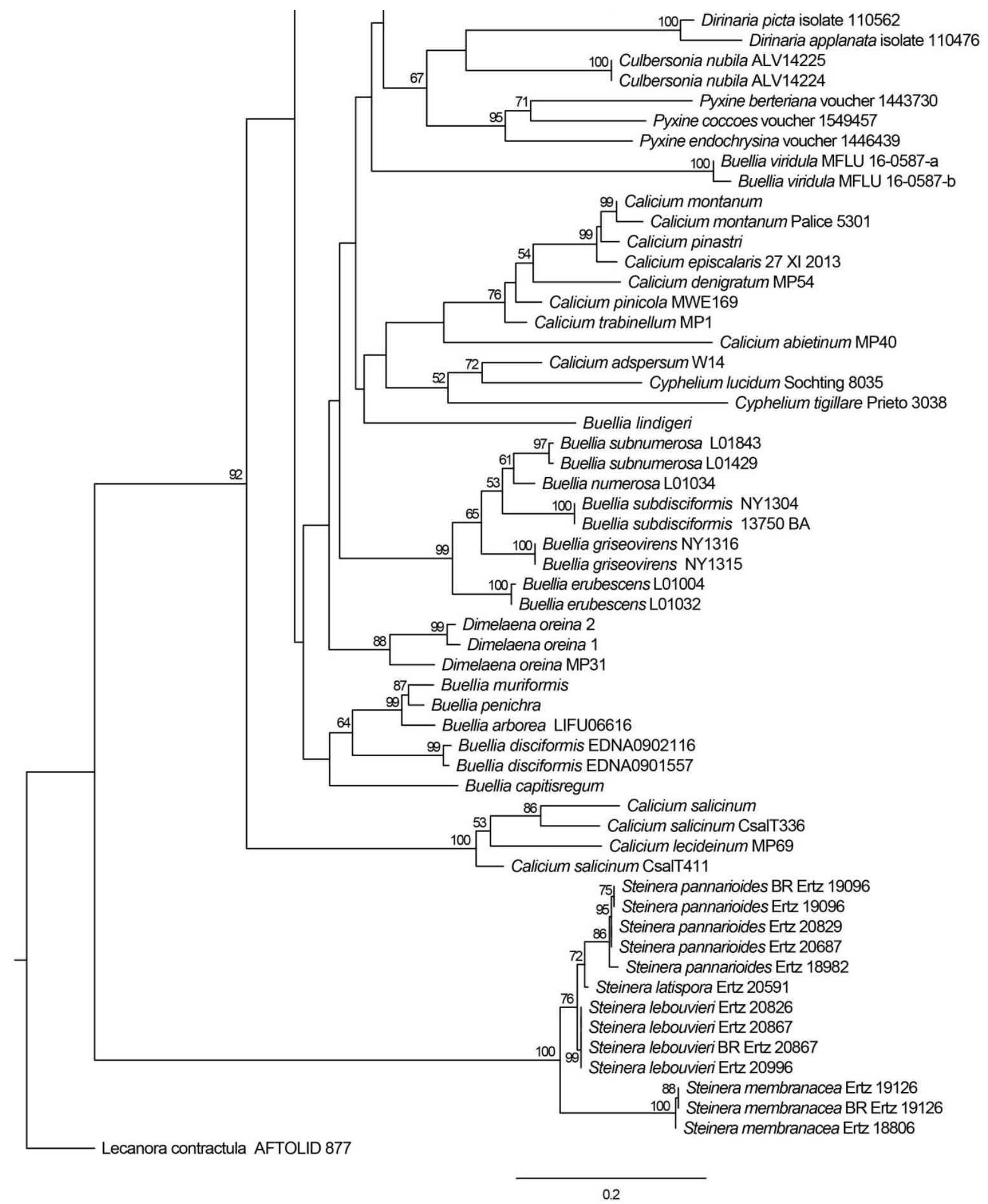

Fig. 9 - Phylogram generated from a maximum likelihood analysis based on ITS sequence data. The newly generated nucleotide sequences were compared against the GenBank (http://www.ncbi.nlm.nih.gov/) database using the Mega BLAST program. Related sequences were obtained from GenBank. One hundred thirty three strains were included in the sequence analyses, which comprised 640 characters including gaps. Lecanora contractula AFTOLID 877 was used as outgroup. The best scoring RAxML tree with a final likelihood value of - 18531.023484 is presented. The matrix had 513 distinct alignment patterns, with $20.64 \%$ of undetermined characters or gaps. Estimated base frequencies were as follows; $\mathrm{A}=0.219, \mathrm{C}=0.289, \mathrm{G}=0.261, \mathrm{~T}$ $=0.231$; substitution rates $\mathrm{AC}=1.437028, \mathrm{AG}=2.537533, \mathrm{AT}=1.696164, \mathrm{CG}=0.808811, \mathrm{CT}=$ $6.126467, \mathrm{GT}=0.474678$; gamma distribution shape parameter $\alpha=1.381352$. Bootstrap support values for ML equal or greater than $50 \%$ are given above the nodes. Newly generated sequences in blue. 


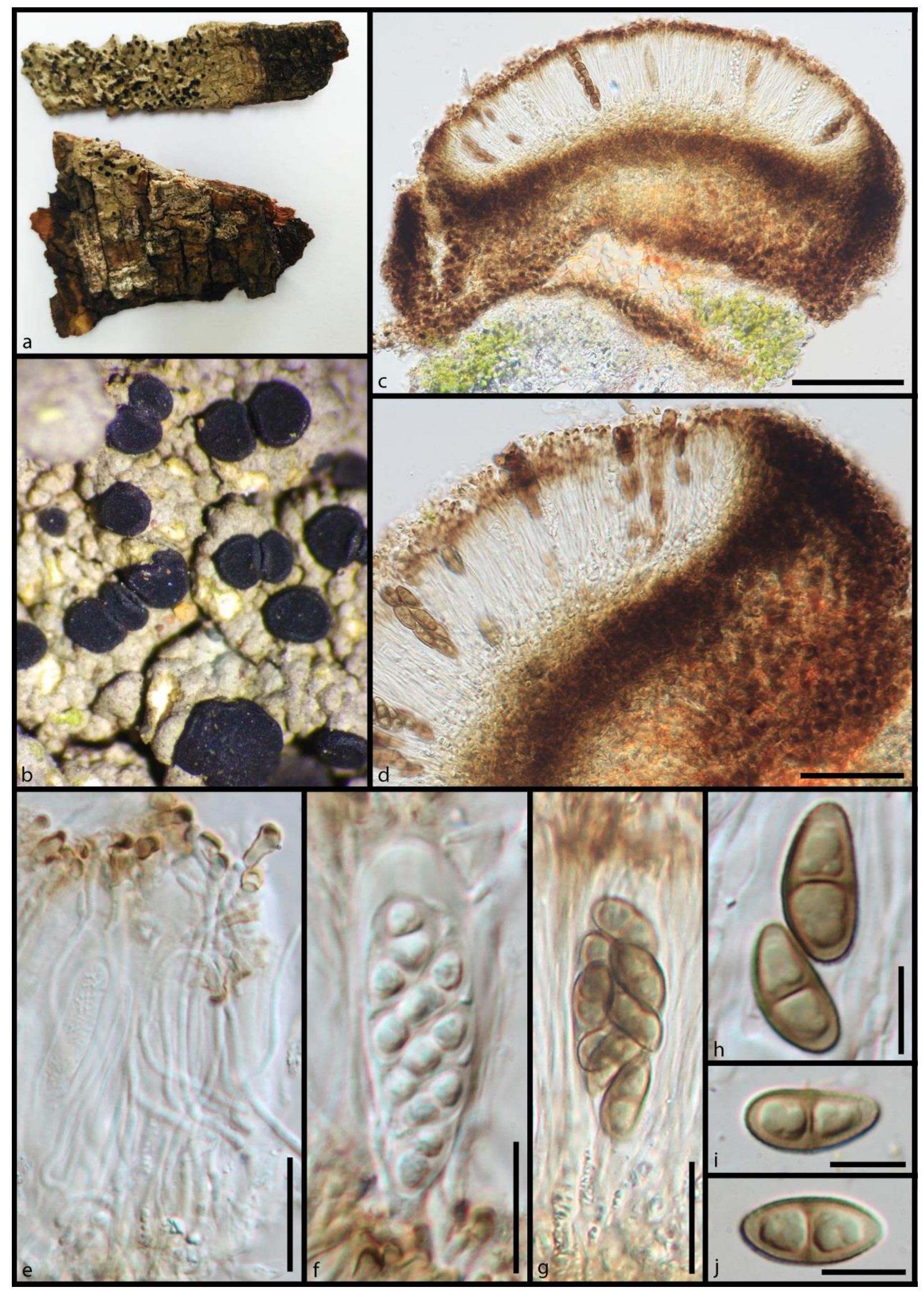

Fig. 10 - Morphology of Buellia sublauri-cassiae (holotype MFLU 18-0672). a Substrate. b Ascomata on wood. c Cross section of an ascoma. d Close up of a vertical section of the ascoma at margin. e Aseptate paraphyses. f, g Short pedicellate asci. h-j Ellipsoid ascospores. Scale bars: c $=100 \mu \mathrm{m}, \mathrm{d}=40 \mu \mathrm{m}, \mathrm{e}-\mathrm{g}=20 \mu \mathrm{m}, \mathrm{h}-\mathrm{j}=10 \mu \mathrm{m}$. 


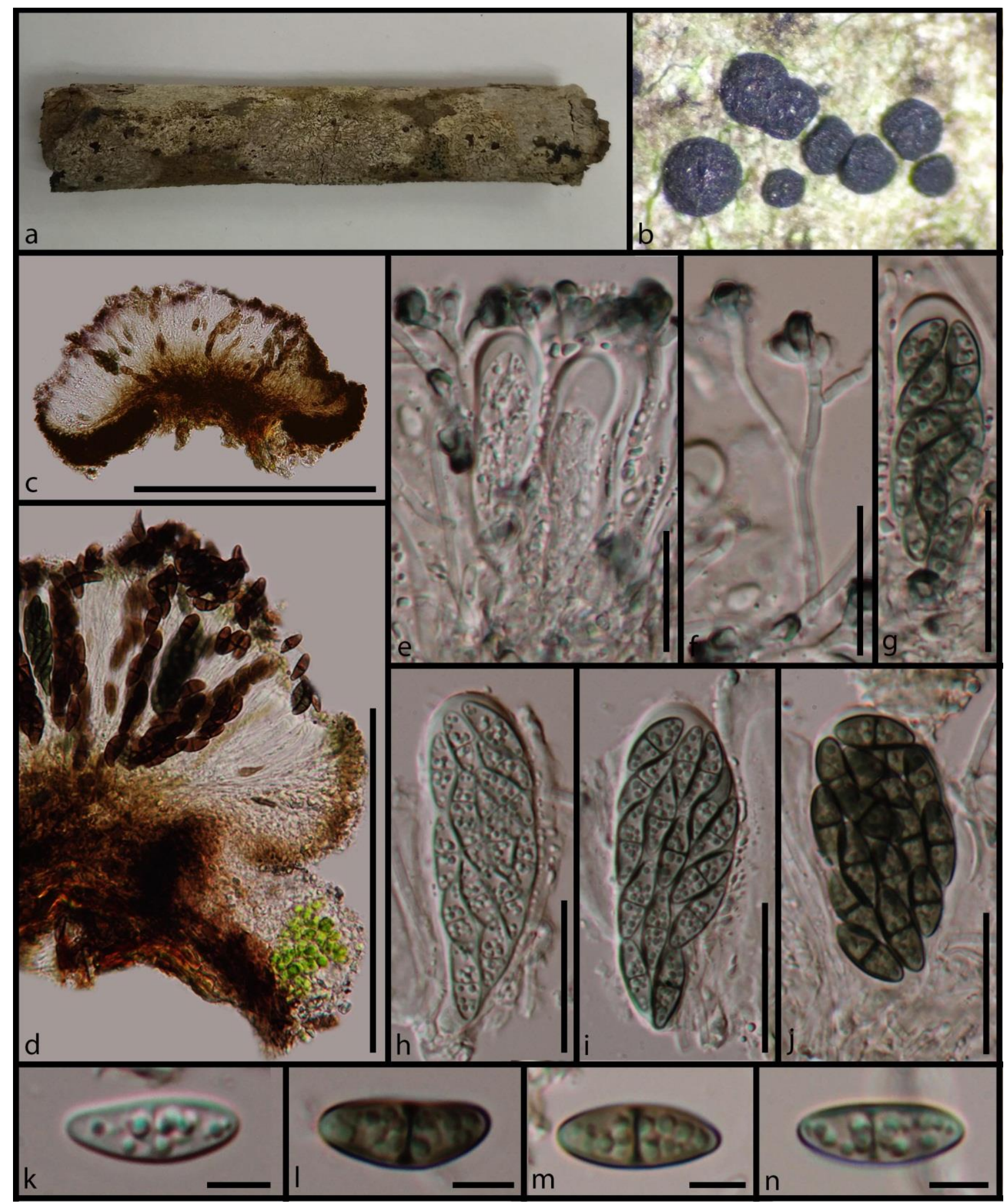

Fig. 11 - Morphology of Buellia polyspora (MFLU 18-0685). a Substrate, b Ascomata on wood. c Cross section of an ascoma. d Close up of a vertical section of the ascoma at margin. e Asci and paraphyses. f Aseptate paraphyses. g-j Short sessile asci. k, n Ellipsoid ascospores. Scale bars: $\mathrm{c}=$ $500 \mu \mathrm{m}, \mathrm{d}=200 \mu \mathrm{m}, \mathrm{e}-\mathrm{j}=40 \mu \mathrm{m}, \mathrm{k}-\mathrm{n}=10 \mu \mathrm{m}$.

the apex. Ascospores 9-11 × 6-7 $\mu m$, multiseriate, ellipsoid, one septate, olive green to brownish, guttulate, smooth, thin walled. Asexual morph: Undetermined.

Material examined - Ukraine, Donetsk region, Shakhtyorsk district, natural landscape park "Donetsk Ridge" ("Donetsky Kryazh" in Russian and Ukrainian), fragment of salty steppe (N 
$47.91320^{\circ}, \mathrm{E} 38.75180^{\circ}$ ), on dead stems of Pontic-Caspian endemic plant Calophaca wolgarica (L. f.) DC. (Fabaceae), 19 May 2017, Timur S. Bulgakov, DNK-071 (MFLU 18-0703).

GenBank accessions - ITS-MK499347, LSU-MK499359

Notes - Our collection of DNK-071 from Ukraine grouped with Rinodina pyrina collections from Sweden and Austria (Fig. 12). The Rinodina pyrina clade of these three strains received a high bootstrap support (93\%) and the ITS data of our new collection shows $99 \%$ similarity to the ITS data of other $R$. pyrina collections (GZU 000272653, Mayrhofer 483). Moreover, morphological characters of our collection are in agreement with the description of Rinodina pyrina provided by Castillo et al. (2013). This species was previously recorded from Ukraine by Gromakova (2011) and Nadyeina (2007), but this is the first record of this species from the natural landscape park "Donetsk Ridge".

\section{Ostropales}

The order Ostropales was introduced by Nannfeldt (1932). Taxa are highly diverse and contain lichenized, lichenicolous, and non-lichenized taxa. Ascomata are apothecial or perithecial (Lumbsch et al. 2007).

\section{Stictidaceae}

The family Stictidaceae was introduced by Fries (1849). Taxa are parasitic, lichenized or lichenicolous and characterized by crustose thalli with chlorococcoid photobiont, ascomata apothecial to perithecial, paraphyses filiform unbranched, asci non-amyloid, cylindrical and ascospores ellipsoid to filiform and sometimes form many by phragmospores (Jaklitsch et al. 2016).

\section{Fitzroyomyces}

The genus Fitzroyomyces was introduced by Crous et al. (2017) and currently includes a single species, Fitzroyomyces cyperacearum. Sexual morphs are not recorded for this genus and asexual morphs are characterised by pycnidial conidiomata (Crous et al. 2017).

Fitzroyomyces cyperacearum Crous, Persoonia 39: 389 (2017)

Fig. 15

= Fitzroyomyces cyperi Crous, Persoonia 39: 389 (2017)

Facesoffungi number: FoF05807

Saprobic on dead stem. Sexual morph: Apothecia $0.4-1 \mathrm{~mm}$ wide, arising singly or in small groups, sessile, immersed from the substrate, cupulate. Hypothecium convex. Disc whitish to cream. Margins white. Hymenium hyaline, enclosed in a thick gelatinous matrix. Epithecium absent. Excipulum 25-35 $\mu \mathrm{m}$ composed of cells of textura intricata. Paraphyses 1.3-2.2 $\mu \mathrm{m}$ wide at the apex, numerous, filiform, aseptate, unbranched. Asci 140-160 × 10-20 $\mu \mathrm{m}, 8$-spored, long cylindrical, short sessile, rounded at the apex. Ascospore 100-150 $\times 2.5-3.5 \mu \mathrm{m}$, multiseriate, filiform, thread like, multi septate, hyaline, sometimes break into fragmospores. Asexual morph: Undetermined.

Material examined - UK, Hampshire, Exton, river bank, on Epilobium ( = Chamaenerion) angustifolium stem, 21 November2016, E.B.G. Jones. GJ339B, GJ317 (MFLU 18-0695a, b)

GenBank accessions - ITS: MFLU 18-0695b-MK499349; LSU: MFLU 18-0695aMK499363, MFLU 18-0695b-MK499361

Notes - Our collection of GJ339 from UK grouped with Fitzroyomyces cyperacearum from Australia (Fig. 14). The Fitzroyomyces cyperacearum clade with three strains received a high bootstrap support (100\%) and ITS data of our strain with $99 \%$ similarity to the ITS data of type species of Fitzroyomyces cyperacearum (CBS: 143170) (data not shown). Fitzroyomyces is an asexual coelomycete genus (Crous et al. 2017). Ascospores of our collection failed to germinate, therefore we are unable to compare the asexual morph characters of our collection with Fitzroyomyces cyperacearum. However, considering genetic similarity, here we placed our 
collection as the sexual morph of $F$. cyperacearum. This is the first sexual morph record of the genus Fitzroyomyces, and the first record from the UK.

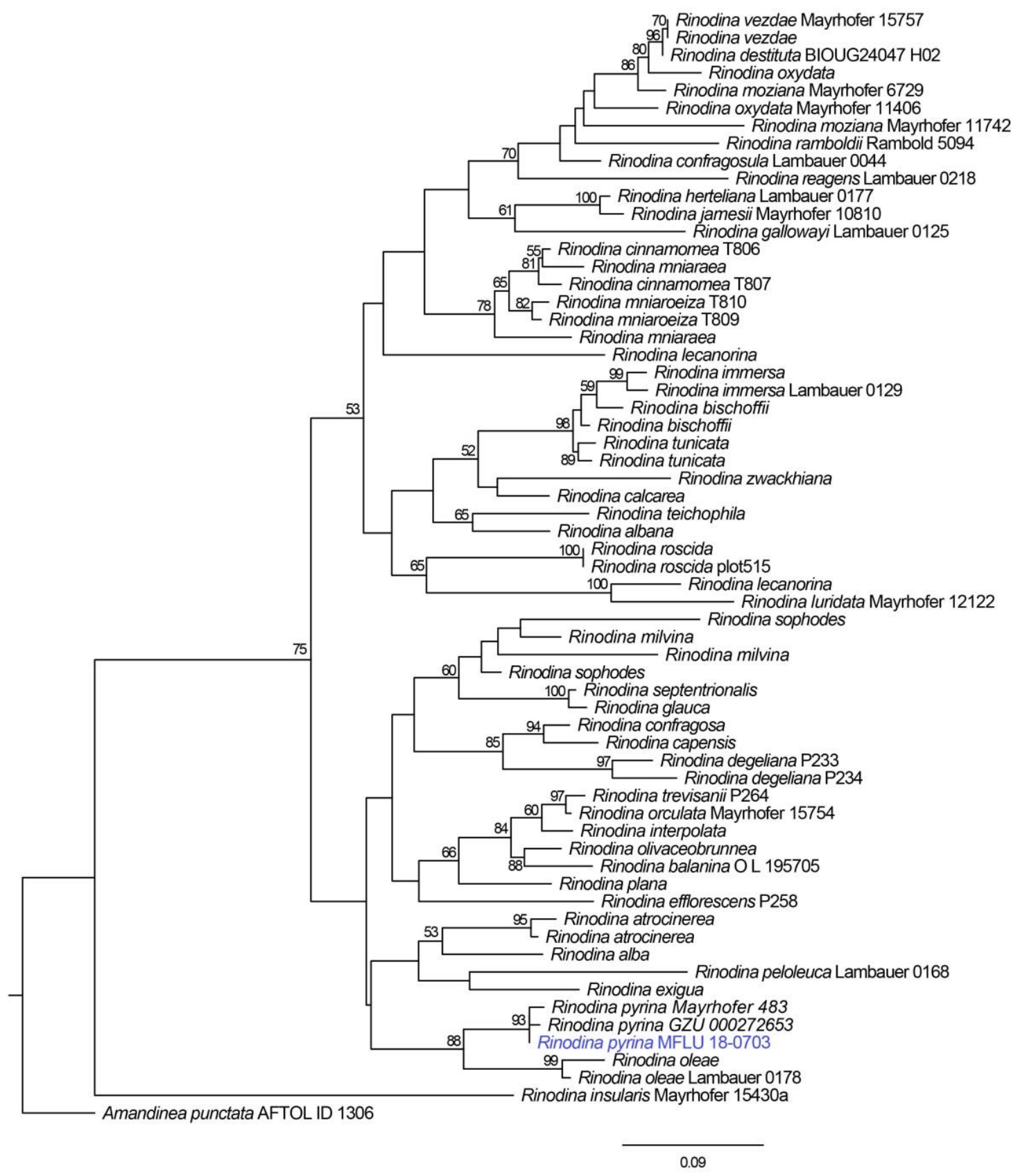

Fig. 12 - Phylogram generated from a maximum likelihood analysis based on ITS sequence data. The newly generated nucleotide sequences were compared against the GenBank (http://www.ncbi.nlm.nih.gov/) database using the Mega BLAST program. Related sequences were obtained from GenBank. Sixty three strains were included in the sequence analyses, which comprised 503 characters including gaps. Amandinea punctata AFTOL ID 1306 was used as outgroup. The best scoring RAxML tree with a final likelihood value of - 7016.886048 is presented. The matrix had 381 distinct alignment patterns, with $13.66 \%$ of undetermined characters or gaps. Estimated base frequencies were as follows; $\mathrm{A}=0.227, \mathrm{C}=0.289, \mathrm{G}=0.245, \mathrm{~T}$ $=0.239$; substitution rates $\mathrm{AC}=1.763724, \mathrm{AG}=2.680923, \mathrm{AT}=1.871963, \mathrm{CG}=0.911919, \mathrm{CT}=$ $6.401303, \mathrm{GT}=1.000000$; gamma distribution shape parameter $\alpha=0.395861$. Bootstrap support values for ML equal or greater than $50 \%$ are given above the nodes. Newly generated sequences in blue. 


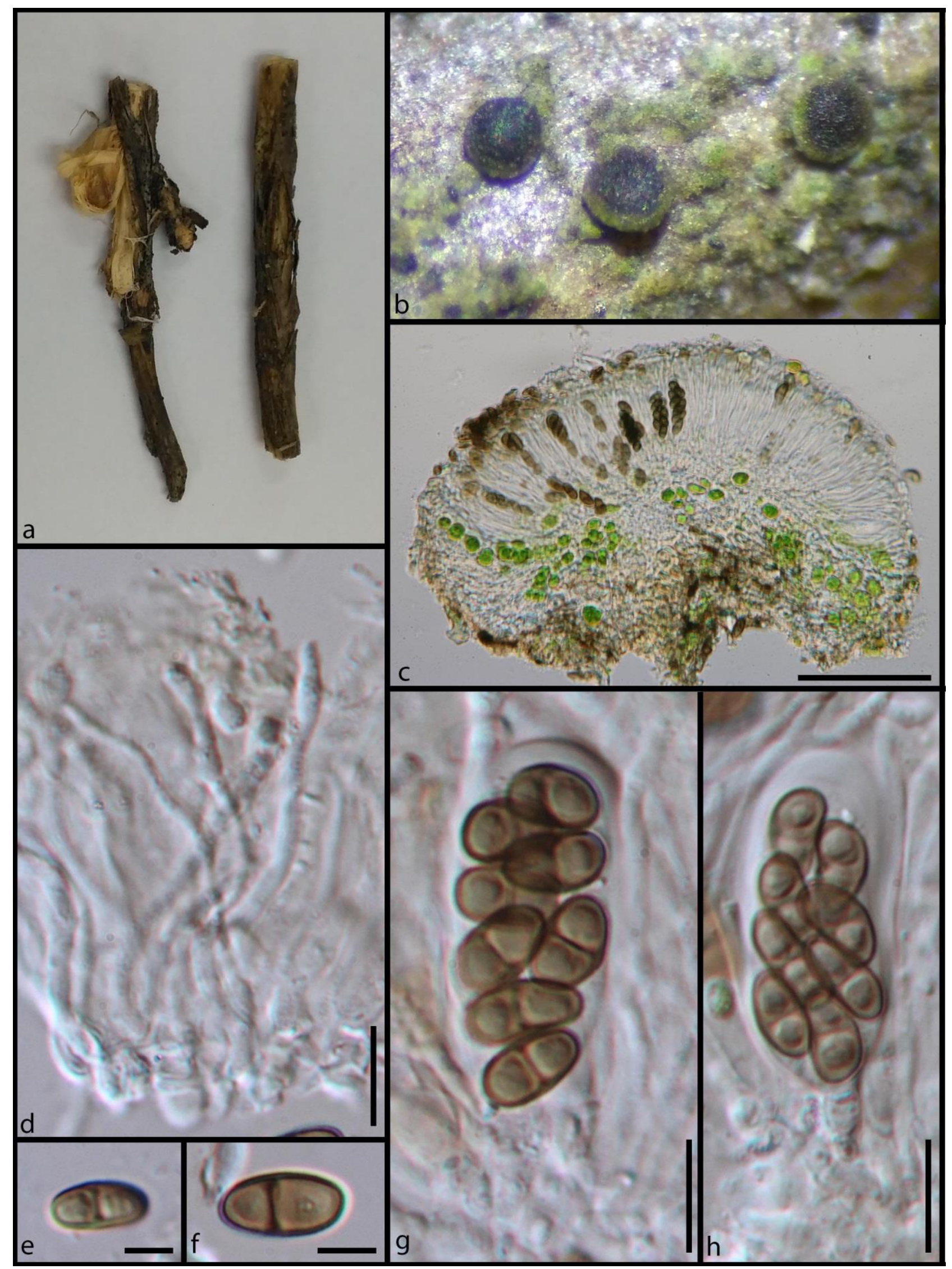

Fig. 13 - Morphology of Rinodina pyrina (MFLU 18-0703). a Substrate. b Ascomata on wood. c Cross section of an ascoma. d Non septate paraphyses. e, f Ellipsoid ascospores. g, h Short sessile asci. Scale bars: $\mathrm{c}=100 \mu \mathrm{m}, \mathrm{d}, \mathrm{g}, \mathrm{h}=15 \mu \mathrm{m}, \mathrm{e}, \mathrm{f}=5 \mu \mathrm{m}$. 


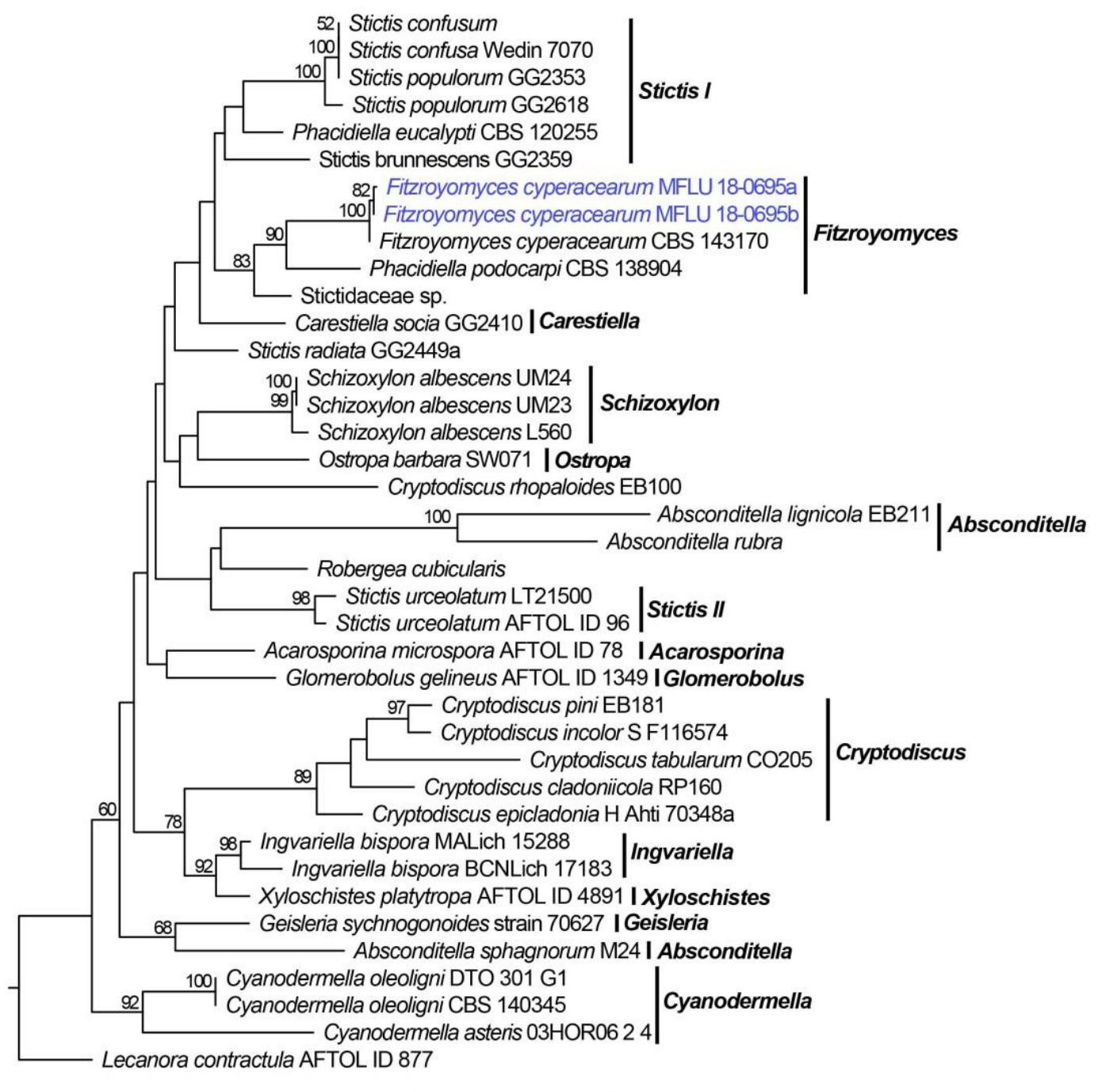

0.2

Fig. 14 - Phylogram generated from a maximum likelihood analysis based on ITS and LSU sequence data. The newly generated nucleotide sequences were compared against the GenBank (http://www.ncbi.nlm.nih.gov/) database using the Mega BLAST program. Related sequences were obtained from GenBank. Thirty-nine strains were included in the sequence analyses, which comprised 577 (ITS-1-556, LSU-557-1511) characters including gaps. Lecanora contractula AFTOL ID 877 was used as outgroup. The best scoring RAxML tree with a final likelihood value of - 13518.083595 is presented. The matrix had 958 distinct alignment patterns, with $48.65 \%$ of undetermined characters or gaps. Estimated base frequencies were as follows; $\mathrm{A}=0.252, \mathrm{C}=$ $0.244, \mathrm{G}=0.276, \mathrm{~T}=0.228$; substitution rates $\mathrm{AC}=1.173341, \mathrm{AG}=1.808670, \mathrm{AT}=1.760640$, $\mathrm{CG}=0.888202, \mathrm{CT}=5.267472, \mathrm{GT}=1.000000$; gamma distribution shape parameter $\alpha=$ 0.339348 . Bootstrap support values for ML equal or greater than $50 \%$ are given above the nodes. Newly generated sequences in blue.

\section{Graphidaceae}

The family Graphidaceae was introduced by Dumortier (1822). Taxa are lichenized and characterised by a crustose thallus with a Trentepohlia photobiont, ascomata apothecial or perithecial, asci annelasceous, non-amyloid, ascospores ellipsoid to oblong, transversely septate to muriform (Jaklitsch et al. 2016).

\section{Glyphis}

The genus Glyphis was introduced by Acharius (1814) and currently includes seven species 
(Jaklitsch et al. 2016, Wijayawardene et al. 2017). Taxa are characterised by crustose thallus, lirelline apothecia and narrow ellipsoid, multi-septate ascospores (Staiger et al. 2006, Archer 2004).

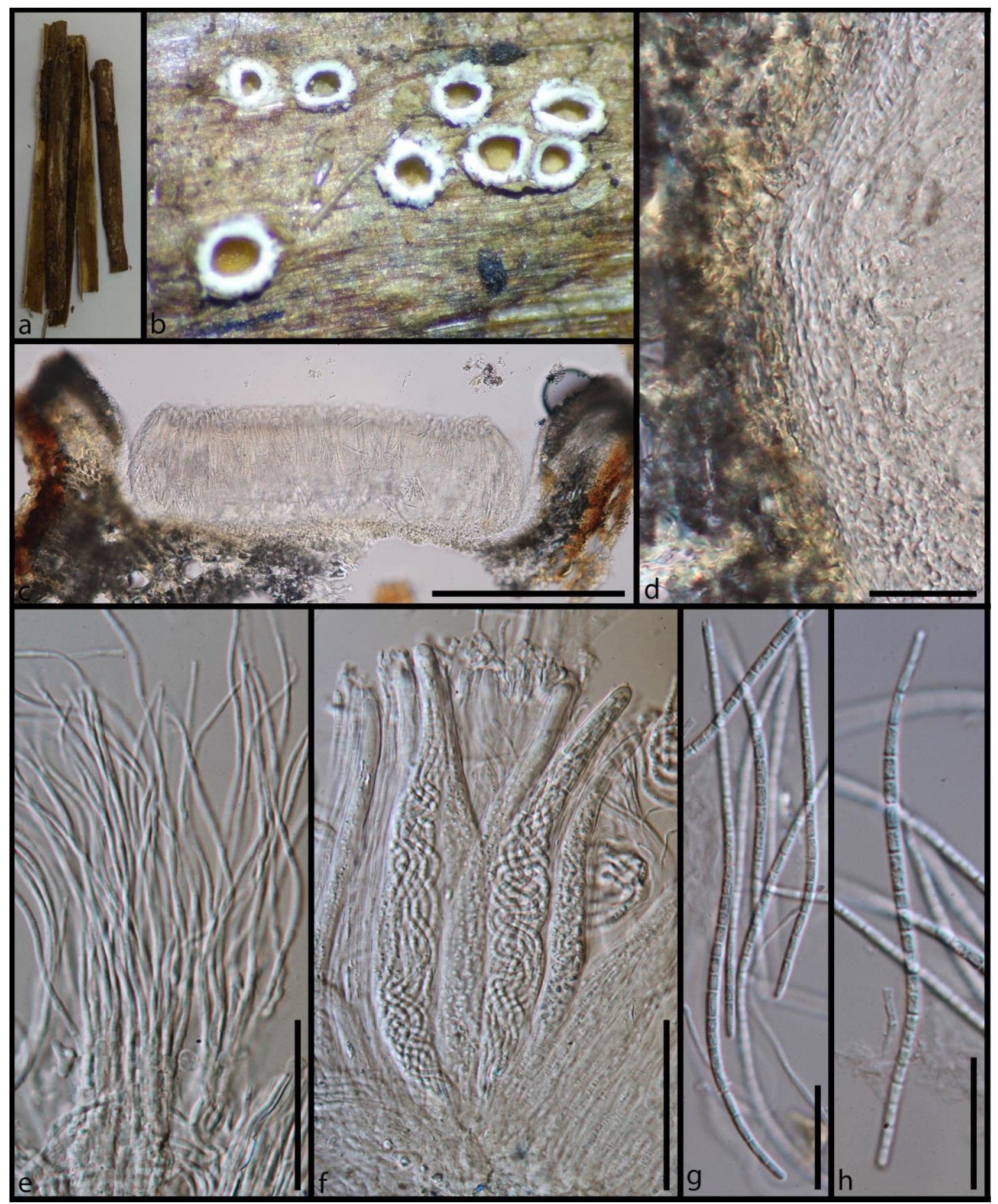

Fig. 15 - Morphology of Fitzroyomyces cyperacearum (MFLU 18-0695a). a Substrate, b Ascomata on woody stem. c Cross section of an ascoma. d Close up of the excipulum. e Non septate paraphyses. $\mathrm{f}$ Long cylindrical asci. g, h Filiform ascospores. Scale bars: $\mathrm{c}=300 \mu \mathrm{m}, \mathrm{d}=25 \mu \mathrm{m}$, $\mathrm{e}, \mathrm{f}=50 \mu \mathrm{m}, \mathrm{g}, \mathrm{h}=25 \mu \mathrm{m}$.

Glyphis cicatricosa Ach., Synopsis Methodica Lichenum: 107 (1814)

Fig. 17 
Facesoffungi number: FoF05808

Lichenized on dead stem. Thallus: crustose, whitish to greenish, photobiont present. Sexual morph: 1-3 mm wide. Compound apothecia arising singly or in small groups, sessile, slightly erumpent from the substrate, pulvinate, blackish, lirelline, stromatic, stroma white, 1-5 apothecia in single stoma, initially rounded, becoming elongate and irregular in outline. Hypothecium convex. Margins black. Hymenium hyaline, within a thick gelatinous matrix. Epithecium slightly branched and pigmented paraphyses apices form clearly distinguishing pseudo epithecium above the hymenium, brownish. Excipulum composed of black, carbonaceous cells of textura angularis. Paraphyses 0.8-1 $\mu \mathrm{m}$ wide, numerous, filiform, septate, apices slightly branched, swollen, pigmented and glued together. Asci 58-66 × 11-16 $\mu \mathrm{m}, 8$-spored, narrowed to base, cylindricclavate, short stipitate, rounded at the apex. Ascospore 28-35 × 5-7 $\mu \mathrm{m}$, hyaline, smooth walled, fusoid, 7-9 septate, guttulate. Asexual morph: Undetermined.

Material examined - Thailand, Chiang Rai Province, Rong Kwang, Phrae, on dead stems, 10 January 2018, A.H. Ekanayaka, HD070 (MFLU 18-0686).

GenBank accessions - ITS- MK499350, LSU- MK499362Notes - Our collection of HD070 from Thailand grouped within the Glyphis cicatricosa complex, especially close to collections from Dominican Republic and Mexico with moderate bootstrap support (56\%) (Fig. 16). Moreover, LSU data of our collection shows $99 \%$ similarity to the LSU data of those collections. The ITS data for Glyphis cicatricose is not available to compare with our data. Furthermore, morphological characters of our collection are in agreement with the description of Glyphis cicatricosa provided by Archer (2004). This species is widely distributed in tropical to temperate regions (Archer 2004). This is the first record of Glyphis cicatricosa from Thailand. Glyphis cicatricosa species complex needs more fresh collections and data from more genetic markers to explain their phylogenetic differences.

\section{Teloschistales}

The order Teloschistales was introduced by Hawksworth \& Eriksson (1986). Taxa are widely distributed and characterised by presence of bright anthraquinone pigments, ranging from yellow to red, in the thallus and/or apothecia (Jaklitsch et al. 2016).

\section{Teloschistaceae}

Taxa are lichenized with a Trebouxia photobiont. Ascomata are apothecial with welldeveloped thalline margins (Gaya et al. 2008). Most Teloschistaceae species produce anthraquinone pigments in the cortex which provides yellow to orange colours to their apothecia (Arup et al. 2013). Paraphyses are unbranched to slightly branched, usually slightly capitate. Asci are semifissitunicate, with apical tholus and distinct ocular chamber. Ascospores are mostly 1-3septate and ellipsoid. The asexual morph is pycnidial (Jaklitsch et al. 2016).

\section{Huriella}

The genus Huriella was introduced by Kondratyuk et al. (2017). Taxa are characterised by a crustose thallus, apothecial ascomata with dull yellow to bright yellow disc, 8-spored asci and polarilocular, small, widely ellipsoid ascospores with rounded ends (Kondratyuk et al. 2017, 2013).

Huriella loekoesiana S.Y. Kondr. \& Upreti, Acta Botanica Hungarica 59 (1-2): 102 (2017) Fig.19 Facesoffungi number: FoF05809

Lichenized on dead stem. Thallus: crustose, grey to black, granulose. Sexual morph: Apothecia $0.2-0.5 \mathrm{~mm}$ wide, arising singly or in small groups, sessile, erumpent from the substrate, cupulate, yellow. Hypothecium convex. Disc yellow. Margins bright yellow. Hymenium hyaline to yellowish, enclosed in a thick gelatinous matrix. Epithecium slightly swollen apices form clearly distinguishing pseudo epithecium above the hymenium, hyaline to yellowish, turned red in $\mathrm{KOH}$. Excipulum 25-35 $\mu \mathrm{m}$ outer cells are textura angularis to globulosa inner layer composed of hyaline loosely arranged hyphae, pigmented, which turns red in $\mathrm{KOH}$. Paraphyses 3-5 $\mu \mathrm{m}$ wide at the 
apex, numerous, filiform, slightly swollen at the apex, septate. Asci 50-60 × 12-18 $\mu \mathrm{m}, 8$-spored, cylindric-clavate, short sessile, rounded at the apex. Ascospores 8-14 $\times 4-7 \mu \mathrm{m}$, multiseriate, ellipsoid, hyaline, guttulate, smooth, thin-walled. Asexual morph: Undetermined.

Material examined - China, Yunnan Province, Botanical garden, Kunming Institute of Botany, Kunming, on dead stems, 24 May 2018, A.H. Ekanayaka, HC24 (HKAS 102112).

GenBank accessions - ITS-MK499351

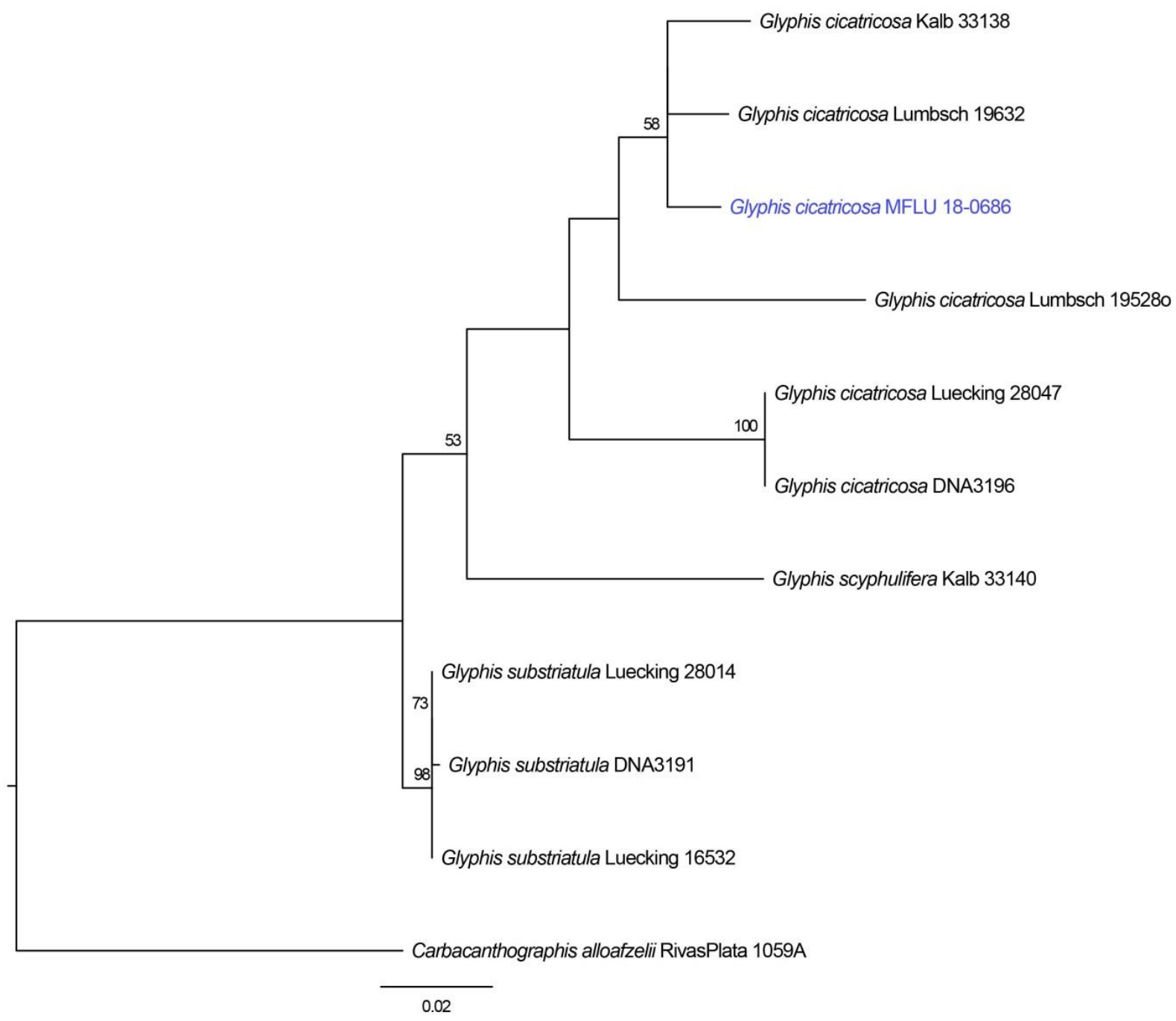

Fig. 16 - Phylogram generated from a maximum likelihood analysis based on LSU sequence data. The newly generated nucleotide sequences were compared against the GenBank (http://www.ncbi.nlm.nih.gov/) database using the Mega BLAST program. Related sequences were obtained from GenBank. Eleven strains were included in the sequence analyses, which comprised 1118 characters including gaps. Carbacanthographis alloafzelii was used as outgroup. The best scoring RAxML tree with a final likelihood value of -2678.762342 is presented. The matrix had 183 distinct alignment patterns, with $21.00 \%$ of undetermined characters or gaps. Estimated base frequencies were as follows; $\mathrm{A}=0.237, \mathrm{C}=0.242, \mathrm{G}=0.311, \mathrm{~T}=0.210$; substitution rates $\mathrm{AC}=$ 0.919706, $\mathrm{AG}=1.835765, \mathrm{AT}=1.178836, \mathrm{CG}=0.742096, \mathrm{CT}=8.397480, \mathrm{GT}=1.000000$; gamma distribution shape parameter $\alpha=0.179099$. Bootstrap support values for ML equal or greater than $50 \%$ are given above the nodes. Newly generated sequences in blue.

Notes - Our collection from China grouped with Huriella loekoesiana collections from South Korea (Fig. 18) and the clade received high bootstrap support. The ITS data of our new collection shows $99 \%$ similarity to the South Korean collections. Moreover, morphological characters of our 
collection are in agreement with the description of $H$. loekoesiana provided by Kondratyuk et al. (2017). This is the first record of $H$. loekoesiana from China.

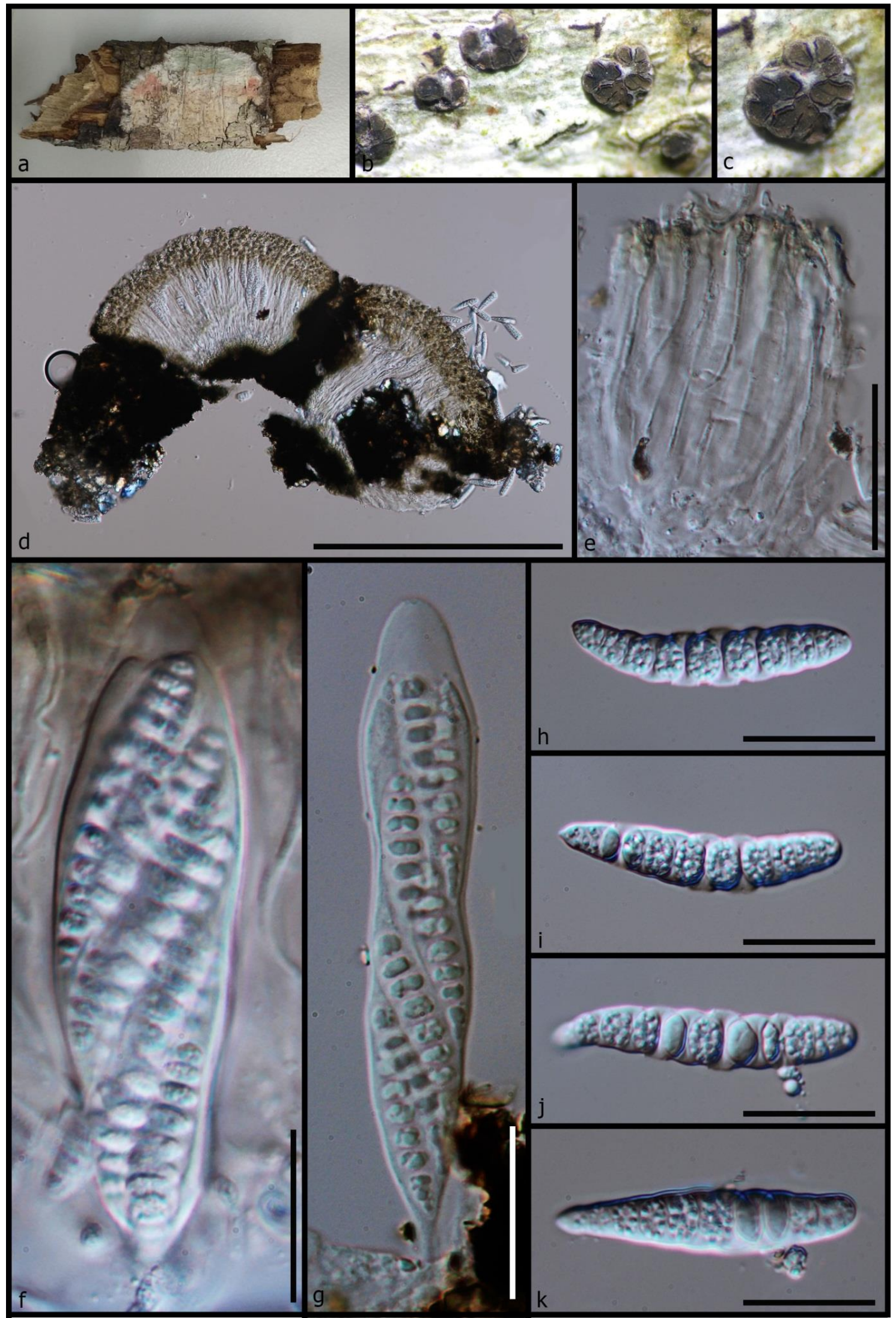

Fig. 17 - Morphology of Glyphis cicatricosa (MFLU 18-0686). a Substrate. b Ascomata on wood. c Ascoma on wood. d Cross section of an ascoma. e Septate paraphyses. f, g Short pedicellate asci. h-k Fusoid ascospores. Scale bars: $\mathrm{d}=200 \mu \mathrm{m}, \mathrm{e}=25 \mu \mathrm{m}, \mathrm{f}-\mathrm{k}=15 \mu \mathrm{m}$. 


\section{Letrouitiaceae}

The family Letrouitiaceae was introduced by Hafellner \& Bellemère (1981). Taxa are characterised by crustose thalli with chlorococcoid photobiont, apothecial ascomata, usually with yellow-orange to purple brown pigments, paraphyses filiform, unbranched to sparingly branched, asci semifissitunicate, weakly amyloid and ellipsoid ascospores (Jaklitsch et al. 2016).

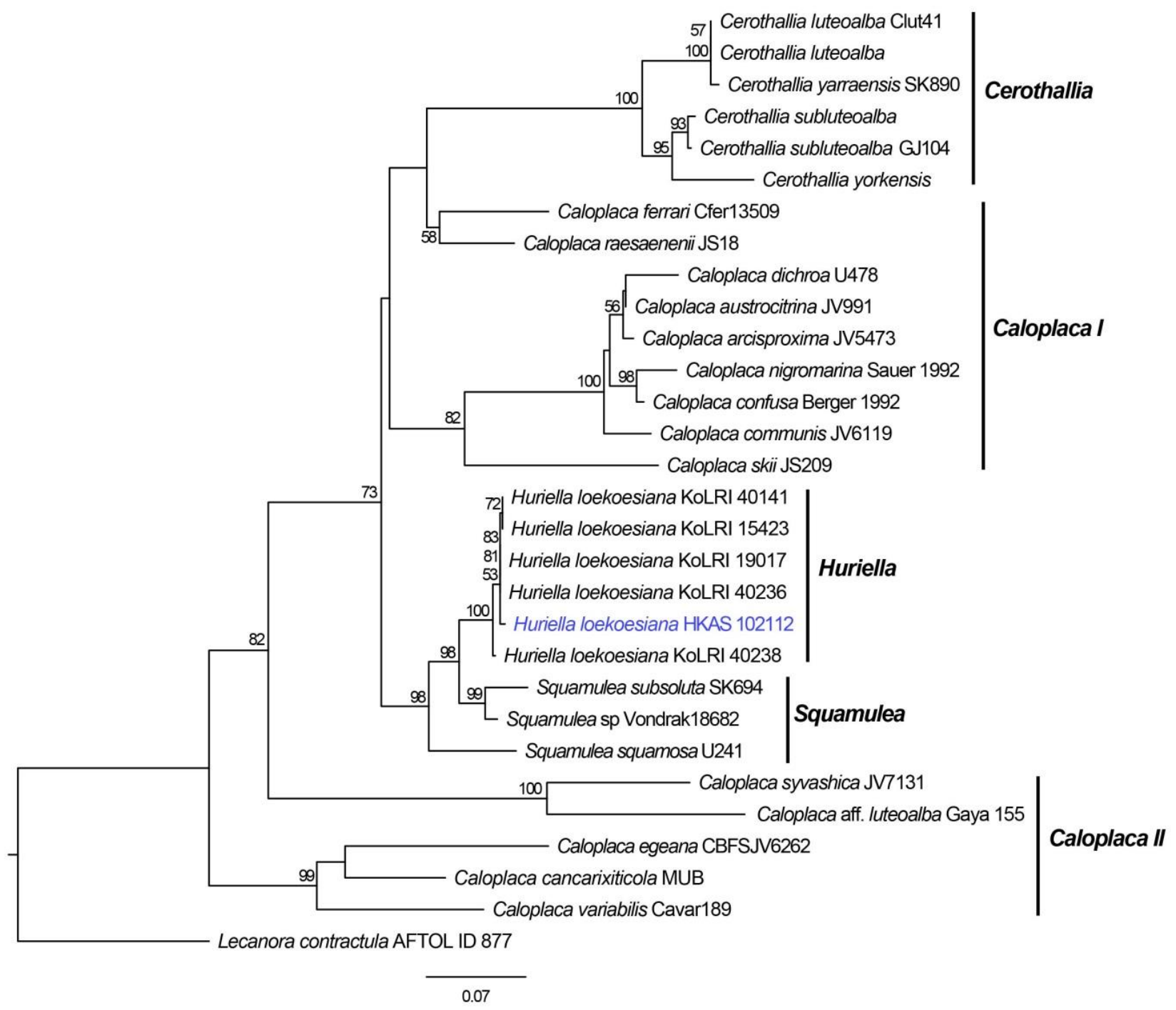

Fig. 18 - Phylogram generated from a maximum likelihood analysis based on ITS sequence data. The newly generated nucleotide sequences were compared against the GenBank (http://www.ncbi.nlm.nih.gov/) database using the Mega BLAST program. Related sequences were obtained from GenBank. Thirty strains were included in the sequence analyses, which comprised 614 characters including gaps. Lecanora contractula AFTOL ID 877 was used as outgroup. The best scoring RAxML tree with a final likelihood value of - 5091.355984 is presented. The matrix had 368 distinct alignment patterns, with $10.48 \%$ of undetermined characters or gaps. Estimated base frequencies were as follows; $\mathrm{A}=0.201, \mathrm{C}=0.289, \mathrm{G}=0.275, \mathrm{~T}=0.234$; substitution rates $\mathrm{AC}=1.507532, \mathrm{AG}=3.448522, \mathrm{AT}=1.874923, \mathrm{CG}=1.471809, \mathrm{CT}=5.994840, \mathrm{GT}=1.000000$; gamma distribution shape parameter $\alpha=0.447974$. Bootstrap support values for ML equal or greater than $50 \%$ are given above the nodes. Newly generated sequences in blue.

\section{Letrouitia}

The genus Letrouitia was introduced by Hafellner \& Bellemère (1981). Currently around 18 species are recorded for this genus (Jaklitsch et al. 2016). Ascospore morphology plays a major role in species delimitation within this genus (Hafellner 1983, Elix \& Kondryatuk 2008). 


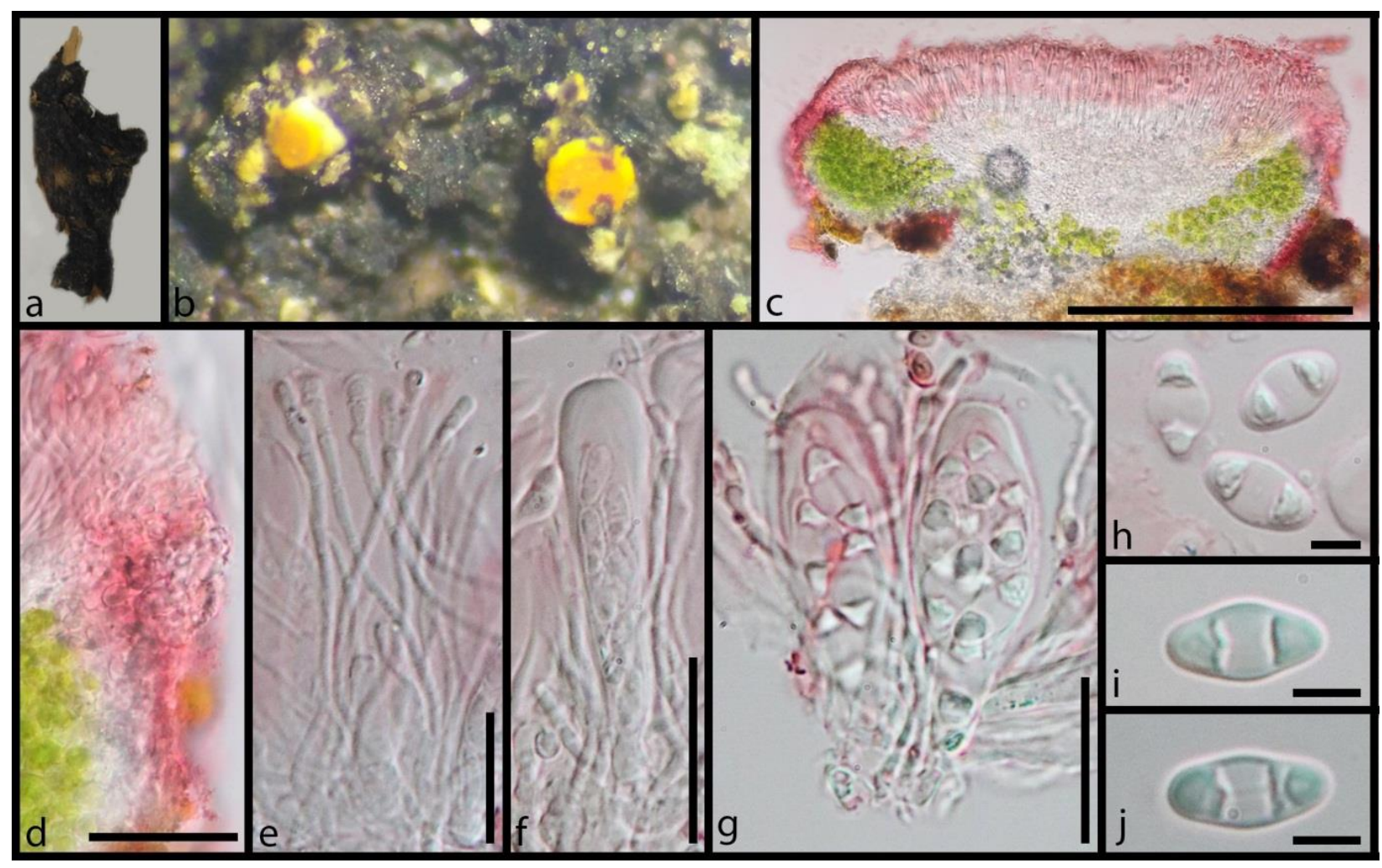

Fig. 19 - Morphology of Huriella loekoesiana (HKAS 102112). a Substrate. b Ascomata on wood. c Cross section of an ascoma. d Close up of a vertical section of the ascoma at margin. e Apically swollen paraphyses. f, g Short sessile asci. h-j Ellipsoid ascospores. (c-j mounted in $\mathrm{KOH}$ ). Scale bars: $\mathrm{c}=50 \mu \mathrm{m}, \mathrm{d}, \mathrm{e}=20 \mu \mathrm{m}, \mathrm{f}, \mathrm{g}=25 \mu \mathrm{m}, \mathrm{h}-\mathrm{j}=5 \mu \mathrm{m}$.

Letrouitia transgressa (Malme) Hafellner \& Bellem., Nova Hedwigia 35: 710 (1983)

Fig. 21

Facesoffungi number: FoF05810

Lichenized on dead stem. Thallus: crustose, greenish yellow, shiny, surface smooth, photobiont present. Sexual morph: Apothecia $0.6-1.3 \mathrm{~mm}$ wide, arising singly or in small groups, sessile, erumpent from the substrate, cupulate, yellow. Hypothecium convex. Disc dark brown. Margins yellow. Hymenium hyaline to yellowish, enclosed in a thick gelatinous matrix, amyloid. Epithecium paraphyses apices glued together to form clearly distinguishing pseudo epithecium above the hymenium, yellowish brown, turned red in $\mathrm{KOH}$. Excipulum 25-35 $\mathrm{\mu m}$ composed of hyaline loosely arranged hyphae, pigmented, which turns red in $\mathrm{KOH}$. Paraphyses $0.8-1 \mu \mathrm{m}$ wide at the apex, numerous, filiform, septate, branched, amyloid. Asci 95-110 × 40-45 $\mu \mathrm{m}, 8$-spored, clavate to subglobose, short sessile, rounded at the apex, amyloid. Ascospores 30-50 $\times 15-18 \mu \mathrm{m}$, multiseriate, ellipsoid-allantoid, hyaline, guttulate, smooth, thin walled, 6-9 transversely spirally septate and 1-2 vertically septate. Asexual morph: Undetermined.

Material examined - Thailand, Chiang Rai Province, Rong Kwang, Phrae, on dead stems, 10 January 2018, A.H. Ekanayaka, HD73 (MFLU 18-0689, reference specimen designated here); same collection details (HKAS 104263)

GenBank accessions - ITS- MK499352, LSU- MK499364

Notes - Our collection from Thailand formed an independent clade with Letrouitia sp. K110 (Fig. 20). Letrouitia transgressa is characterized by yellow apothecia with a reddish brown to brown disc and ellipsoid ascospores with primarily 6-9 transverse septa, becoming progressively submuriform (1-3 vertical septa) (Joshi et al. 2013). Morphological characters of our strain are similar to the description of Letrouitia transgressa provided by Joshi et al. (2013). Sequence data for L. transgressa is not available in GenBank to compare with our new collection. Letrouitia transgressa is a widespread species in both tropical and temperate regions. Johansson et al. (2005) also recorded this species from Thailand. This is the first record of molecular data for the species. 
Therefore here we introduce this collection as a reference specimen (sensu Ariyawansa et al. 2014) for Letrouitia transgressa.

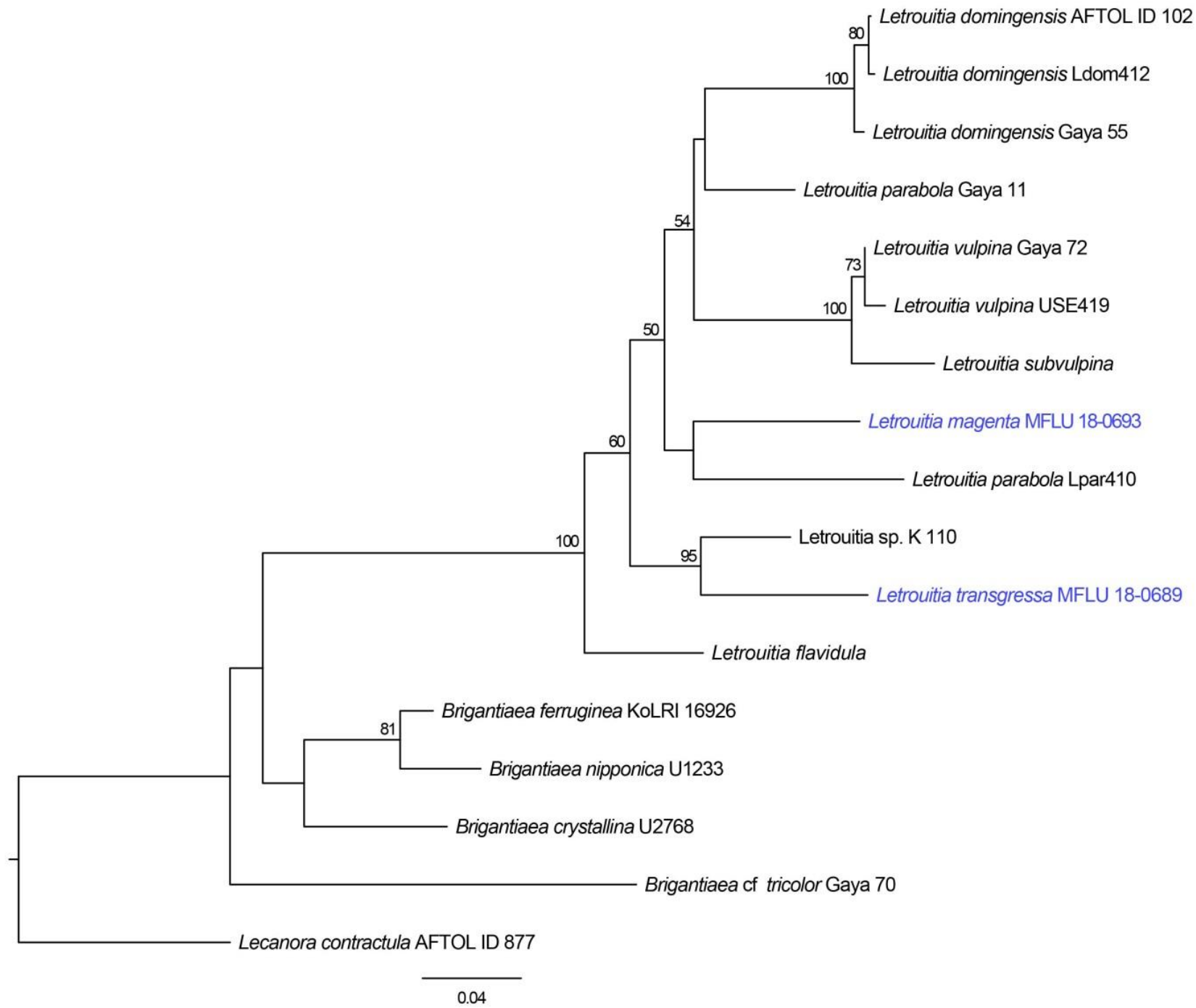

Fig. 20 - Phylogram generated from a maximum likelihood analysis based on ITS and LSU sequence data. The newly generated nucleotide sequences were compared against the GenBank (http://www.ncbi.nlm.nih.gov/) database using the Mega BLAST program. Related sequences were obtained from GenBank. Seventeen strains were included in the sequence analyses, which comprised 1503 (ITS-1-638, LSU-639-1503) characters including gaps. Lecanora contractula AFTOL ID 877 was used as outgroup. The best scoring RAxML tree with a final likelihood value of - 6381.437779 is presented. The matrix had 456 distinct alignment patterns, with $36.69 \%$ of undetermined characters or gaps. Estimated base frequencies were as follows; $\mathrm{A}=0.238, \mathrm{C}=$ $0.250, \mathrm{G}=0.284, \mathrm{~T}=0.228$; substitution rates $\mathrm{AC}=1.140713, \mathrm{AG}=2.817251, \mathrm{AT}=1.930229$, $\mathrm{CG}=1.180207, \mathrm{CT}=7.018144, \mathrm{GT}=1.000000$; gamma distribution shape parameter $\alpha=$ 0.198611 . Bootstrap support values for ML equal or greater than $50 \%$ are given above the nodes. Newly generated sequences in blue.

Letrouitia magenta Ekanayaka \& K.D. Hyde, sp. nov.

Fig. 22

Index Fungorum number: IF556243; Facesoffungi number: FoF05811

Etymology - refers to the disc colour, magenta

Holotype - MFLU 18-0693

Lichenized on dead stem. Thallus: crustose, grey to green, granulose, photobiont present. Sexual morph: Apothecia $0.8-1.2 \mathrm{~mm}$ wide, arising singly or in small groups, sessile, erumpent 


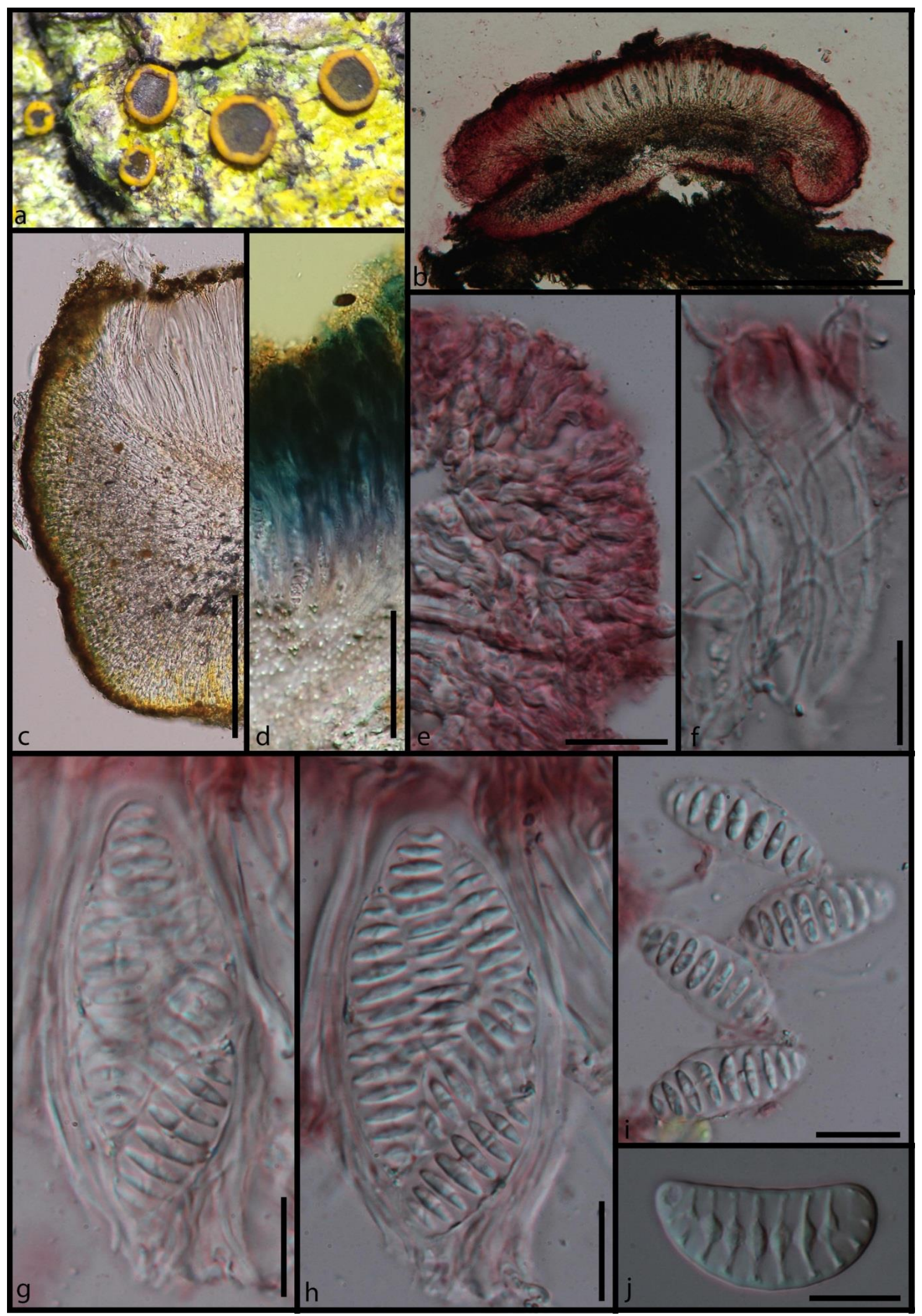

Fig. 21 - Morphology of Letrouitia transgressa (MFLU 18-0689). a Ascomata on wood. b Cross section of an ascoma. c Close up of a vertical section of the ascoma at margin and flank. $d$ Part of hymenium layer in Melzer's reagent. e Excipular cells. f Branched paraphyses. g-h Clavate asci. i-j Ellipsoid ascospores. (b, e-j mounted in KOH). Scale bars $-b=100 \mu \mathrm{m}, \mathrm{c}, \mathrm{d}=60 \mu \mathrm{m}, \mathrm{e}=25$ $\mu \mathrm{m}, \mathrm{f}-\mathrm{j}=20 \mu \mathrm{m}$. 


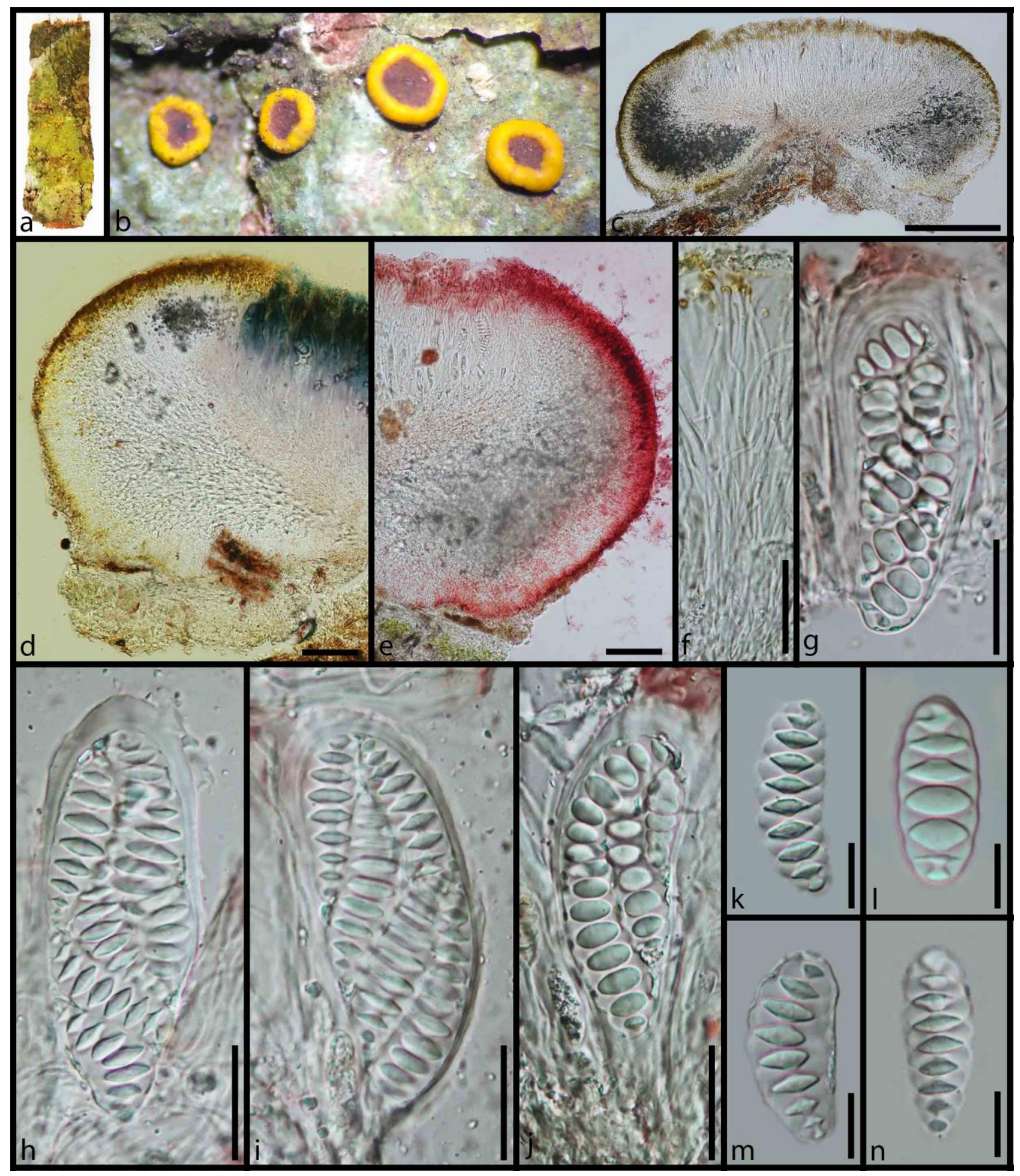

Fig. 22 - Morphology of Letrouitia magenta (holotype MFLU 18-0693). a Substrate. b Ascomata on wood. c Cross section of an ascoma. d, e Close up of a vertical section of the ascoma at margin and flank. f Branched paraphyses. g-j Clavate asci. k-n Ellipsoid ascospores. (e, g-n-mounted in $\mathrm{KOH}, \mathrm{d}-$ mounted in Melzer's reagent). Scale bars $-\mathrm{c}=200 \mu \mathrm{m}, \mathrm{d}, \mathrm{e}=50 \mu \mathrm{m}, \mathrm{f}-\mathrm{j}=30 \mu \mathrm{m}, \mathrm{k}-\mathrm{n}=$ $15 \mu \mathrm{m}$.

from the substrate, cupulate, yellow. Hypothecium convex. Disc orange-brown to magenta. Margins bright yellow. Hymenium hyaline, enclosed in a thick gelatinous matrix. Epithecium slightly swollen and pigmented paraphyses apices form clearly distinguishing pseudo epithecium above the hymenium, yellowish brown, turned red in KOH. Excipulum 25-35 $\mu \mathrm{m}$ composed of hyaline loosely arranged hyphae, pigmented, which turns red in $\mathrm{KOH}$. Paraphyses $1.8-2.2 \mu \mathrm{m}$ 
wide at the apex, numerous, filiform, slightly swollen at the apex, septate, branched. Asci $90-110 \times$ 25-30 $\mu \mathrm{m}, 8$-spored, clavate to sub-globose, short sessile, rounded at the apex. Ascospores $28-45 \times$ 10-15 $\mu \mathrm{m}$, multiseriate, ellipsoid, hyaline, guttulate, smooth, thin walled, 6-9 transversely spirally septate. Asexual morph: Undetermined.

Material examined - Thailand, Chiang Rai Province, Rong Kwang, Phrae, on dead bark, 10 January 2018, A.H. Ekanayaka, HD80 (MFLU 18-0693, holotype), (HKAS 104263, isotype)

GenBank accessions - ITS- MK499353, LSU-MK499365

Notes - Our collection from Thailand clustered with Letrouitia parabola Lpar410 (Gaya et al. 2008) (Fig. 20), but with low bootstrap support (44\%). ITS data of our collection $86 \%$ similar to Letrouitia domingensis (Gaya 55) and 85\% similar to that of Letrouitia parabola (Gaya 11). Morphology of our collection similar to L. parabola (Elix 2009), but differs in having smaller asci. Letrouitia parabola was previously recorded from coastal forest in north-eastern Queensland, North America, Asia, Papua New Guinea and New Caledonia (Elix 2009). Considering these facts here we introduce new species, Letrouitia magenta from Thailand. Letrouitia magenta is similar to L. transgressa in having submuriform ascospores at maturity, but differs in lacking transverse septa. However, the ascospores of L. magenta have a spiral septation (Joshi et al. 2013).

\section{Acknowledgements}

This study was supported by the National Natural Science Foundation of China (No. 31360015) and the CAS/SAFEA International Partnership Program for Creative Research Teams, and the Knowledge Innovation Program of the Chinese Academy of Sciences (No. KSCX2-EW-Z9 KIB2016002). Kevin D. Hyde would like to thank the Thailand Research Funds entitled Impact of climate change on fungal diversity and biogeography in the Greater Mekong Subregion (grant no: RDG6130001). Damien Ertz is thanked for valuable comments and suggestions during manuscript preparation. Gareth Jones is supported by a Distinguished Scientist Fellowship Program (DSFP), King Saud University, Kingdom of Saudi Arabia. Anusha H. Ekanayaka is grateful to Mr. W. Ekanayaka (deceased), Mrs. C. Ekanayaka and Mr. A. Surasinghe for their valuable support and encouragement.

\section{References}

Acharius E. 1814 - Synopsis Methodica Lichenum, 1-392.

Agardh CA. 1821 - Aphorismi botanici 87-102.

Archer AW. 2004 - The lichen genera Cyclographina, Diplogramma, Glyphis, Gymnographa, Medusulina, Sarcographa and Sarcographina (Graphidaceae) in Australia. Telopea 10, 589605.

Ariyawansa HA, Hawksworth DL, Hyde KD, Jones EG et al. 2014 - Epitypification and neotypification: guidelines with appropriate and inappropriate examples. Fungal Diversity 69, 57-91.

Arup U, Søchting U, Frödén P. 2013 - A new taxonomy of the family Teloschistaceae. Nordic Journal of Botany 31, 016-83.

Awasthi DD, Mathur R. 1987 - Species of the lichen genera Bacidia, Badimia, Fellhanera and Mycobilimbia from India. Proceedings: Plant Sciences, 97, 481-503.

Bates ST, Cropsey GW, Caporaso JG, Knight R, Fierer N. 2011 - Bacterial communities associated with the lichen symbiosis. Applied and Environmental Microbiology 77, 1309-1314.

Berbee ML, Taylor JW. 1992 - Two Ascomycetes classes based on fruiting body characters and ribosomal DNA sequence. Molecular Biology and Evolution 9, 278-284.

Bessey CE. 1907 - A synopsis of plant phyla. University of Nebraska Studies 7, 275-373.

Bungartz F, Elix JA, Nash III TH. 2004 - The genus Buellia sensu lato in the greater Sonoran desert region: saxicolous species with one-septate ascospores containing xanthones. Bryologist 107, 459-479. 
Bungartz F, Nordin A, Grube U. 2007 - Buellia. In: Nash TH, Gries C, Bungartz F, editors. Lichen flora of the greater Sonoran desert region, Vol. III. Tempe: Arizona State University, Lichens Unlimited.

Castillo RV, Ibaceta A, Vergara E. 2013 - Rinodina pyrina (Physciaceae, Ascomycota) new to Chile/Rinodina pyrina (Physciaceae, Ascomycota) nueva especie para Chile. Gayana Botanica 70, 398.

Chevallier FF. 1826 - Flore Générale des Environs de Paris 1, 1-674.

Crespo A, Kauff F, Divakar PK, del Prado R et al. 2010 - Phylogenetic generic classification of parmelioid lichens (Parmeliaceae, Ascomycota) based on molecular, morphological and chemical evidence. Taxon 59, 1735-1753.

Crous PW, Wingfield MJ, Burgess TI, Carnegie AJ et al. 2017 - Fungal Planet description sheets: 625-715. Persoonia 39, 270-467.

De Notaris G. 1846 - Frammenti lichenografici di un lavoro inedito. Giornale Botanico Italiano 2, $174-224$.

Dumortier BC. 1822 - Commentationes botanicae. 1-116.

Ekanayaka AH, Ariyawansa HA, Hyde KD, Jones EBG et al. 2017 - DISCOMYCETES: The apothecial representatives of the phylum Ascomycota. Fungal Diversity 87, 237-298

Elix JA. 2009 - Letrouitia parabola (Nyl.) R.Sant. \& Hafellner, https://www.anbg.gov.au/abrs/lichenlist/VOLUME\%2057/Letrouitia\%20parabola_d.html (accessed on January 2019)

Elix JA. 2011 - Rinodina, Australian Physciaceae (Lichenised Ascomycota). http://www.anbg.gov.au/abrs/lichenlist/Rinodina.pdf.

Elix JA, Kondryatuk SY. 2008 - Two new species of Letrouitia (Letrouitiaceae: Ascomycota) from Australia. Australasian Lichenology 62, 16-9.

Engler A. 1898 - Syllabus der Pflanzenfamilien

Ertz D, Miadlikowska J, Lutzoni F, Dessein S et al. 2009 - Towards a new classification of the Arthoniales (Ascomycota) based on a three- gene phylogeny focusing on the genus Opegrapha. Mycological Research 113, 141-152.

Fedorenko NM, Stenroos S, Thell A, Kärnefelt I et al. 2012 - Molecular phylogeny of xanthorioid lichens (Teloschistaceae, Ascomycota), with notes on their morphology. In: Kärnefelt I, Seaward MRD, Thell A. (Eds.), Systematics, Biodiversity and Ecology of lichens. Biblotheca Lichenologica.

Fries EM. 1849 - Summa vegetabilium Scandinaviae 2, 259-572.

Gaya E, Navarro-Rosinés P, Llimona X, Hladun N, Lutzoni F. 2008 - Phylogenetic reassessment of the Teloschistaceae (lichen-forming Ascomycota, Lecanoromycetes). Mycological Research 112, 528-546.

Gerasimova JV, Ezhkin AK, Andreas BECK. 2018 - Four new species of Bacidia (Ramalinaceae, Lecanorales) in the Russian Far East. The Lichenologist 50, 603-625.

Gray SF. 1821 - A natural arrangement of British plants 1, 1-824.

Gromakova AB. 2011 - Lichens of Botanical Reserve "Volchanskiy" (Kharkov region, Ukraine) // Вісник Харківського національного університету імені ВН Каразіна. Серія: Біологія 13, $57-62$.

Grube M, Baloch E, Arup U. 2004 - A phylogenetic study of the Lecanora rupicola group (Lecanoraceae, Ascomycota). Mycological Research 108, 506-514.

Gueidan C, Hill DJ, Miadlikowska J, Lutzoni F. 2014 - Pezizomycotina: Lecanoromycetes. In: McLaughlin DJ, Spatafora JW. (Eds.), The Mycota Part B, vol. VII. Springer Verlag, Berlin, Germany.

Gumboski EL, Sionara S, da Silveira RMB. 2014 - Extending the distribution of Ramalina lacera (With.) JR Laundon (Ramalinaceae, lichen forming Ascomycota): First record from eastern South America. Check List 10, 195-198.

Hafellner J. 1984 - Studien in Richtung einer natürlicheren Gliederung der Sammelfamilien Lecanoraceae und Lecideaceae. Nova Hedwigia 79, 241-371. 
Hafellner J. 1993 - Die Gattung Pyrrhospora in Europa. Eine erste Übersicht mit einem Bestimmungsschlüssel der Arten nebst Bemerkungen zu einigen aussereuropäischen Taxa (lichenisierte Ascomycotina, Lecanorales). Herzogia 9, 725-747.

Hafellner J, Bellemère A. 1981 - Elektronenoptische Untersuchungen an Arten der Flechtengattung Letrouitia gen. nov. Nova Hedwigia 35, 263-312.

Hall T. 2004 - BioEdit. Ibis Therapeutics, Carlsbad, CA, 92008, USA. http://www.mbio.ncsu.edu/ BioEdit/bioedit.html.

Hawksworth DL, Eriksson OE. 1986 - The names of accepted orders of Ascomycetes. Systema Ascomycetum 5, 175-184.

Ismailov A, Urbanavichus G, Vondrák J, Pouska V. 2017 - An old-growth forest at the Caspian Sea coast is similar in epiphytic lichens to lowland deciduous forests in Central Europe. Herzogia 30, 103-25.

Jaklitsch W, Baral HO, Lücking R, Lumbsch HT, Frey W. 2016 - Ascomycota. In: Frey, W. (ed.) Syllabus of Plant Families -Adolf Engler's Syllabus der Pflanzenfamilien. Borntraeger, Stuttgart.

James TY, Kauff F, Schoch CL, Matheny PB et al. 2016 - Establishing species boundaries and new taxa among fungi: recommendations to resolve taxonomic ambiguities. Mycosphere 7, 16691677.

Jayasiri SC, Hyde KD, Ariyawansa HA, Bhat J et al. 2015 - The Faces of Fungi database: fungal names linked with morphology, phylogeny and human impacts. Fungal Diversity 74, 3-18.

Jeewon R, Hyde KD. 2016 - Establishing species boundaries and new taxa among fungi: recommendations to resolve taxonomic ambiguities. Mycosphere 7, 1669-1677.

Johansson S, Søchting U, Elix JA, Wardlaw JH. 2005 - Chemical variation in the lichen genus Letrouitia (Ascomycota, Letrouitiaceae). Mycological Progress 4, 139-148.

Joseph S, Nayaka S, Randive P, Upreti DK. 2018 - New records and a key to the species of Malmidea (lichenized Ascomycota) from India. Feddes Repertorium 129, 189-192.

Joshi S, Nguyen TT, Dzung NA, Jayalal U et al. 2013 - New records of corticolous lichens from Vietnam. Mycotaxon 123, 479-489.

Joshi Y, Wang XY, Lökös L, Koh YJ, Hur JS. 2010 - Notes on lichen genus Buellia De Not. (lichenized Ascomycetes) from South Korea. Mycobiology 38, 65-69.

Kalb K, Plata ER, Lücking R, Lumbsch HT. 2011 - The phylogenetic position of Malmidea, a new genus for the Lecidea piperis - and Lecanora granifera-groups (Lecanorales, Malmideaceae), inferred from nuclear and mitochondrial ribosomal DNA sequences, with special reference to Thai species. Biblotheca Lichenologica 106, 143-168.

Kalb K, Hafellner J. 1992 - Bemerkenswerte Flechten und lichenicole Pilze von der Insel Madeira. Herzogia 9, 45-102.

Kirk P, Cannon PF, Minter DW, Stalpers JA. 2008 - Ainsworth \& Bisby's dictionary of the fungi, 10th edn. CAB International, Wallingford.

Kondratyuk SY, Lökös L, Upreti DK, Nayaka S et al. 2017 - New monophyletic branches of the Teloschistaceae (lichen-forming Ascomycota) proved by three gene phylogeny. Acta Botanica Hungarica59, 71-136.

Kondratyuk S, Jeong MH, Yu NH, Kärnefelt I et al. 2013 - Four new genera of teloschistoid lichens (Teloschistaceae, Ascomycota) based on molecular phylogeny. Acta Botanica Hungarica 55, 251-274.

Körber GW. 1855 - Systema lichenum Germaniae 1-458.

Lucking R, Hodkinson BP, Leavitt SD. 2016 - The 2016 classification of lichenized fungi in the Ascomycota and Basidiomycota- approaching one thousand genera. Bryologist 119, 361416.

Lumbsch HT, Schmitt I, Lücking R, Wiklund E, Wedin M. 2007 - The phylogenetic placement of Ostropales within Lecanoromycetes (Ascomycota) revisited. Mycological Research 111, 257-267. 
Lutzoni F, Kauff F, Cox CJ, McLaughlin D et al. 2004 - Assembling the Fungal Tree of Life Assembling the fungal tree of life: progress, classification, and evolution of subcellular traits. American Journal of Botany 91, 1446-1480.

Luyken JA. 1809 - Tentamen Historiae Lichenum in Genere, cui Accedunt Primae Lineae Distributionis Novae 1-102.

Miadlikowska J, Kauff F, Högnabba F, Oliver JC et al. 2014 - Multigene phylogenetic synthesis for the class Lecanoromycetes (Ascomycota): 1307 fungi representing 1139 infrageneric taxa, 312 genera and 66 families. Molecular Phylogenetics and Evolution 79, 132-168.

Miller MA, Pfeiffer W, Schwartz T. 2010 - Creating the CIPRES Science Gateway for inference of large phylogenetic trees. Gateway Computing Environments Workshop (GCE), 1-8.

Nannfeldt JA. 1932 - Studien über die Morphologie und Systematik der nichtlichenisierten inoperculaten Discomyceten. Nova Acta Regiae Societatis Scientiarum Upsaliensis 8, 1-368.

Nadyeina OV. 2007 - The lichens of national nature park (Svyaty Gory). Chornomors'k. bot. z. 3: $100-108$.

Prieto M, Wedin M. 2016 - Phylogeny, taxonomy and diversification events in the Caliciaceae. Fungal Diversity 82, 221-238.

Prieto M, Schultz M, Olariaga I, Wedin M. 2018 - Lichinodium is a new lichenized lineage in the Leotiomycetes. Fungal Diversity https://doi.org/10.1007/s13225-018-0417-5

Schoch CL, Wang Z, Townsend JP, Spatafora JW. 2009 - Geoglossomycetes cl. nov., Geoglossales ord. nov., and taxa above class rank in the Ascomycota tree of life. Persoonia 22, 129-138.

Scheidegger C. 1993 - A revision of European saxicolous species of the genus Buellia de Not. and formerly included genera. The Lichenologist 25, 315-64.

Schultz M, Arendholz WR, Budel AB. 2001 - Origin and evolution of the lichenized ascomycete order Lichinales: monophyly and systematic relationships inferred from ascus, fruiting body and SSU rDNA evolution. Plant Biology 3, 116-123.

Sheard JW, May PF. 1997 - A synopsis of the species of Amandinea (Lichenized Ascomycetes, Physciaceae) as presently known in North America. The Bryologist 100, 159-169.

Śliwa L. 2007 - A revision of the Lecanora dispersa complex in North America. Polish Botanical Journal 52, 1-70.

Śliwa L, Miadlikowska J, Redelings BD, Molnar K, Lutzoni F. 2012 - Are widespread morphospecies from the Lecanora dispersa group (lichen-forming Ascomycota) monophyletic? The Bryologist 115, 265-277.

Staiger B, Kalb K, Grube M. 2006 - Phylogeny and phenotypic variation in the lichen family Graphidaceae (Ostropomycetidae, Ascomycota). Mycological Research 110, 765-772

Spribille T, Tuovinen V, Resl P, Vanderpool D et al. 2016 - Basidiomycete yeasts in the cortex of ascomycete macrolichens. Science 353, 488-492.

Vilgalys R, Hester M. 1990 - Rapid genetic identification and mapping of enzymatically amplified ribosomal DNA from several Cryptococcus species. Journal of Bacteriology 172, 4238-4246.

Villesen P. 2007 - FaBox: an online toolbox for fasta sequences. Molecular Ecology Notes 7, 965968.

Watanuki O, Hara K, Harada H, Komine M, Fuji SI. 2017 - Buellia numerosa and B. subnumerosa, two new species of the lichen genus Buellia (Caliciaceae) from Japan. The Bryologist 120, $25-36$.

Weerakoon G, Wolseley PA, Arachchige O, da Silva E et al. 2016 - Eight new lichen species and 88 new records from Sri Lanka. The Bryologist 119, 131-142.

White TJ, Bruns T, Lee S, Taylor JW. 1990 - Amplification and direct sequencing of fungal ribosomal RNA genes for phylogenetics. In: Innis MA, Gelfand DH, Sninsky JJ, White TJ (eds) PCR protocols: a guide to methods and applications. New York Academic Press. pp 315-322.

Wijayawardene NN, Hyde KD, Rajeshkumar KC, Hawksworth DL et al. 2017 - Notes for genera: Ascomycota. Fungal diversity 86, 1-594. 
Zhurbenko M, Notov A. 2015 - The lichenicolous lichen Placocarpus americanus and some noteworthy lichenicolous fungi from Russia. Folia Cryptogamica Estonica 19, 95-99. 